\title{
أثر السياق في دلالة الخروج المجازي لأسلوب النداء في النص القرآني
}

أ.م.دعزيز سليم القريشي

$$
\text { بسم الله الرحمن الرحيم }
$$

في النص القرآني دلالات لا تعد ولا تحصى مهما تعددت الدراسات واختلفت المشارب والآراء

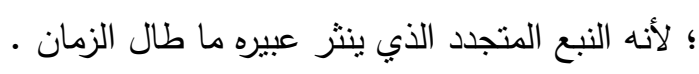

والنداء بوصفه أسلوبا نحويا وبلاغيا شاع وروده في القران الكريم، قد تم تتاوله من حيث الحقيقة

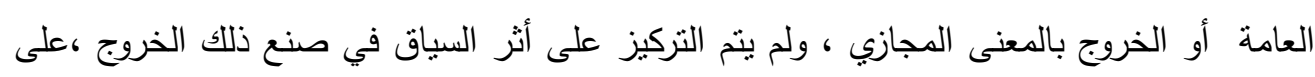

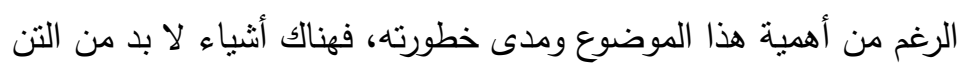

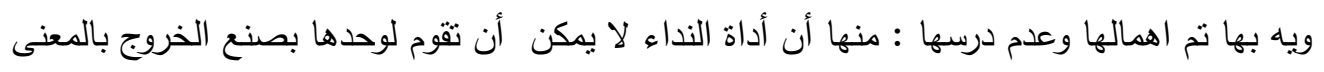

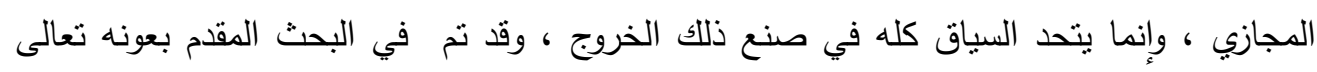

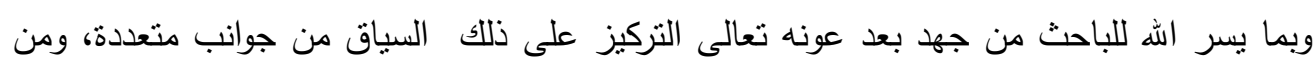

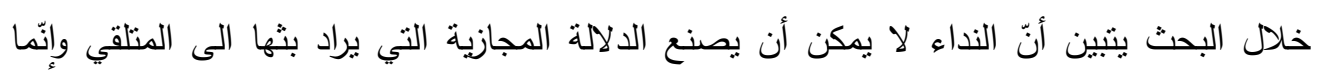

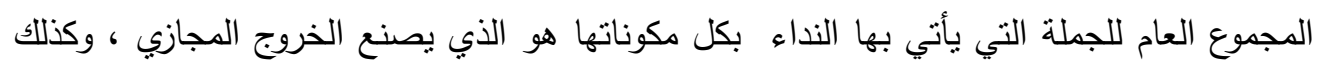

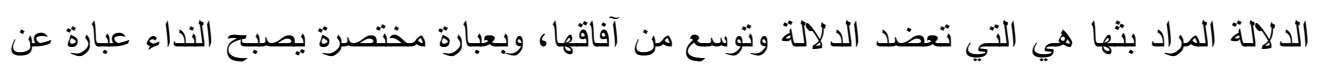
أداة تثير الانتباه للطرح الدقدم الذي هو السياق الذي يقاس عليه خروج النداء المجازي ودلالته ) . وقبل الدخول في تفاصيل البحث لا بد من التعريف بإيجاز بالنداء بوصفه أسلوبا نحويا، وبابا من أبواب علم المعاني في البلاغة العربية .

النداء : هو تتبيه المخاطب أو المقبل ليقبل عليك بحرف ناب مناب الفعل (أدعو ) لفظا وتقدير|) 
أو هو طلب المنادى بأحد احرف النداء ().

والنداء في باب علم المعاني البلاغي لا يختلف عن تعريفه النحوي المتقدم ، و لا ينم إلا

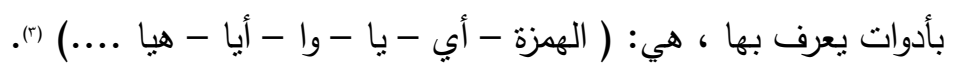

ولكل أداة من هذه الأدوات دلالنها ، فالأداتان (الهمزة ، أي ) تستعملان لمناداة الثخص

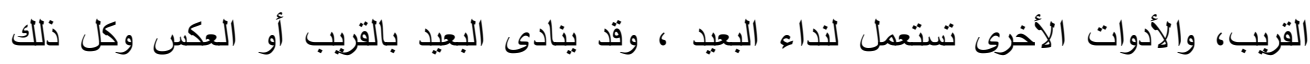

لالالات مقصودة ـ (s)

والاتصال بين البلاغة و النحو في باب النداء شيء لا يمكن اغفاله، لأنهما متلازمان في كثف الدلالة وهذا هو عبد القاهر الجرجاني يقول في حديثه عن نظرية النظم التي تقوم على فهم

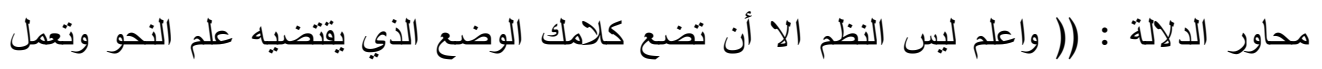

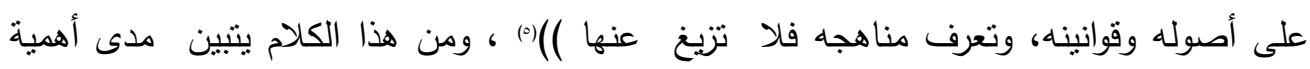

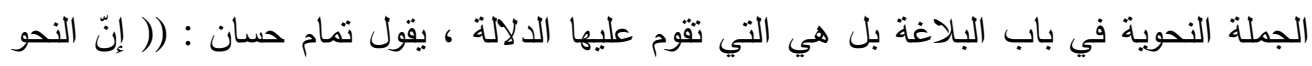

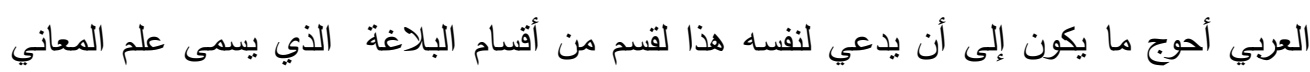

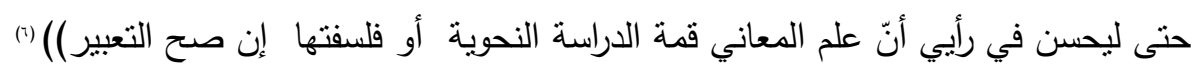

وقد جاء النداء في القران الكريم بأوجه متعددة وبدلالات منتوعة غير أنّ ماهية الدلالة لا

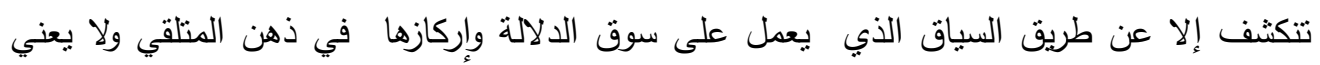

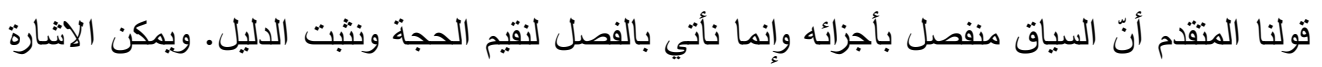

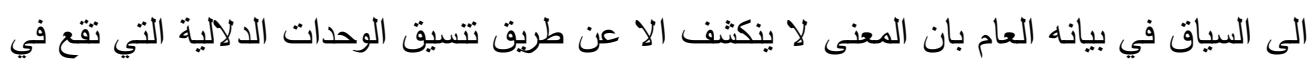

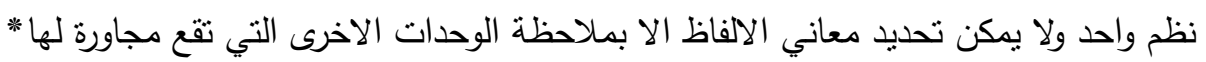


الجمل وأثرها في دلالة النداء

والجمل أنواع متعددة منها الفعلية أو الأسمية أو الحكائية أو الثرطية أو الخبرية وكل له علاقة وثيقة بالسياق الذي يعمل على تفعيل دلالة النداء فمثلا، تأني الجملة الحكائية (مقول القول)

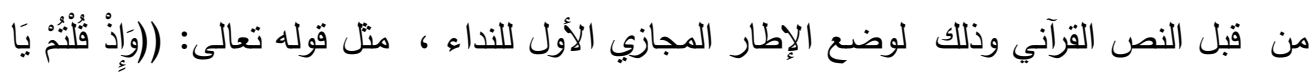

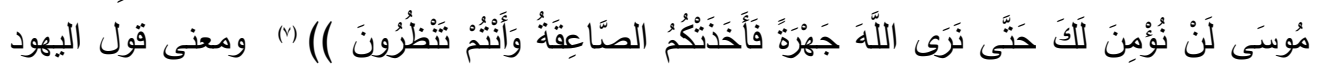

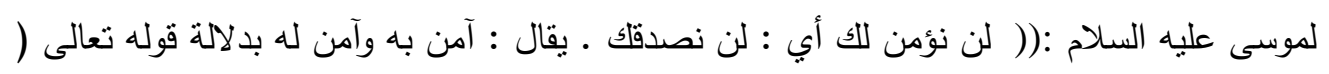

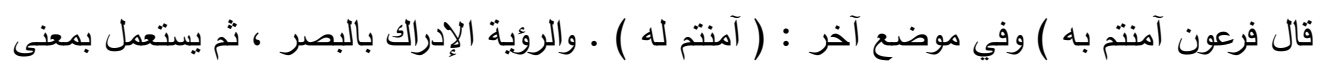

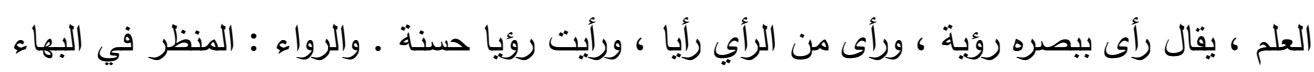

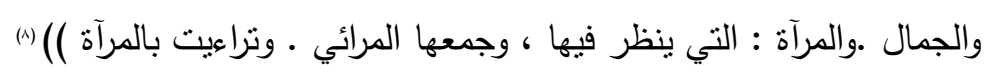

فالنص القرآني يتمثل أمام القارىء ويضع اللبنة الأولى لماهية التعجب ، التي تتمثل من قبل

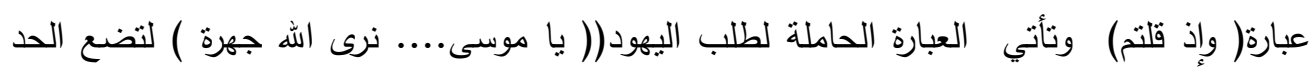

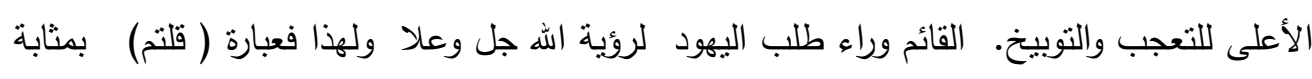

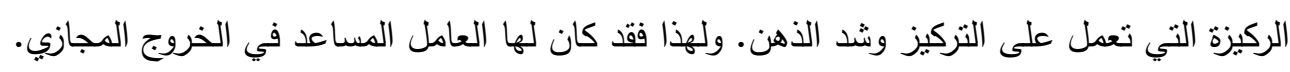

إنّ التحفيز القرآني لا يتضح من خلال النداء فحسب وإنما الذي يحدده طبيعة السياق

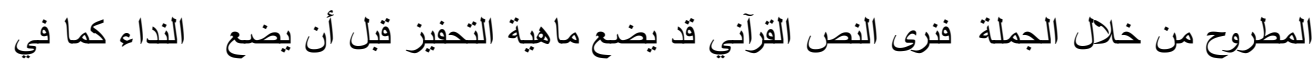

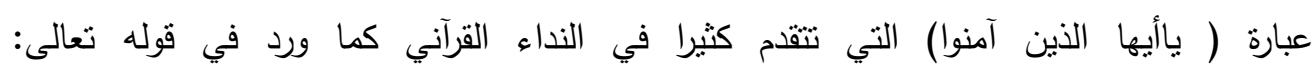

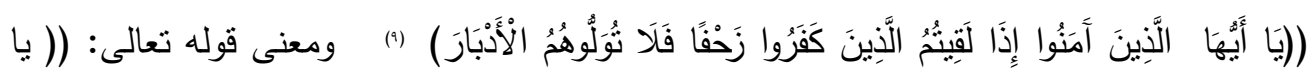

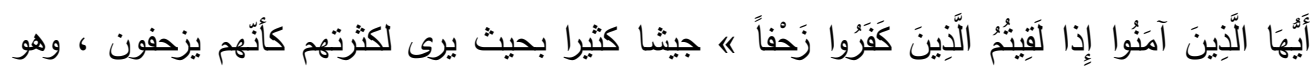

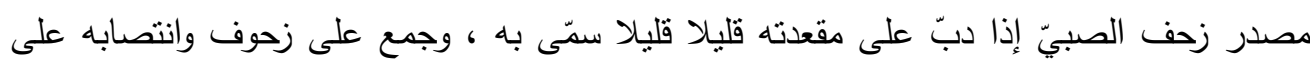

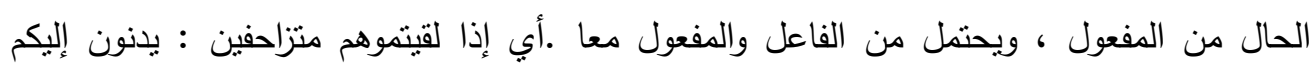

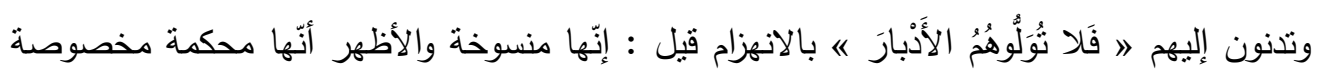

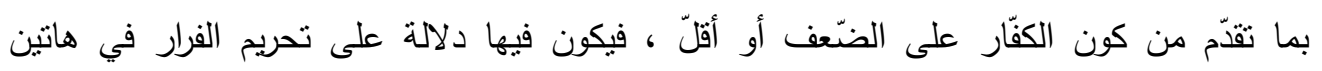

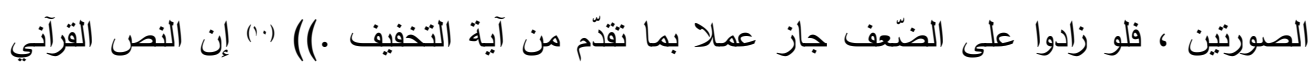

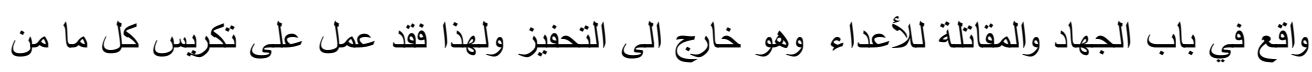

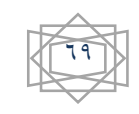


شأنه أن يصعد من الروح المعنوية للمسلمين والظاهر من عبارة( يا أيها الذين آمنوا ) بداية التحفيز

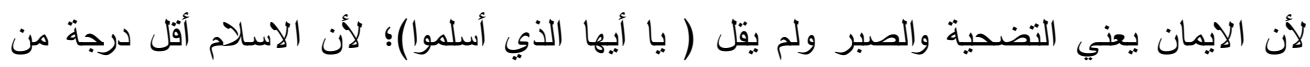

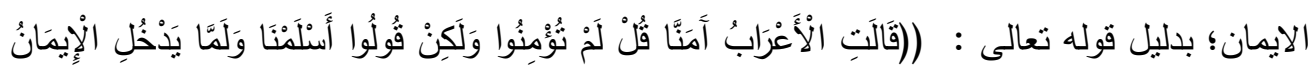

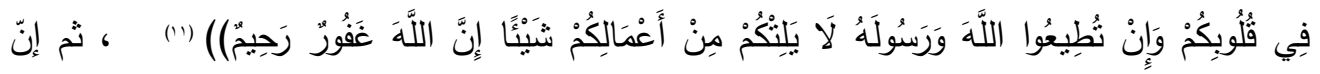

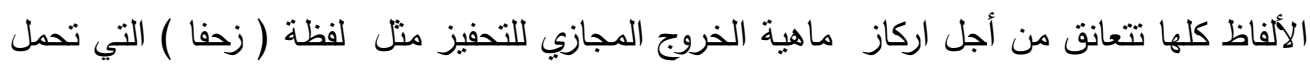

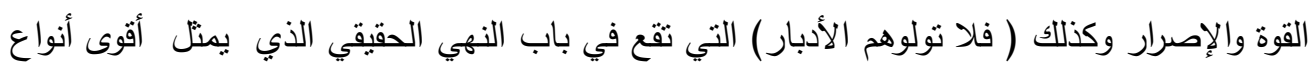

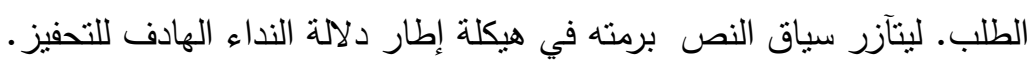

وقد يشكل سياق الجملة الثرطية القرآنية أطر دلالة الاستقهام ويحدد معالمه كما في قوله

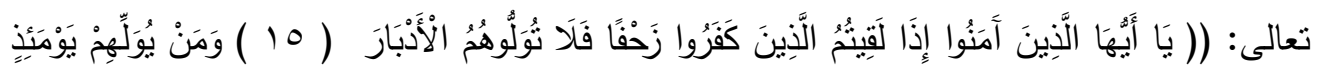

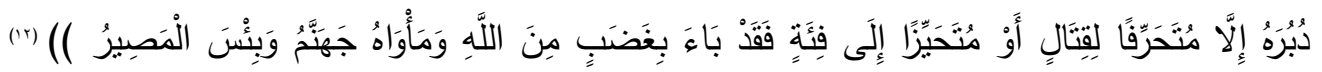

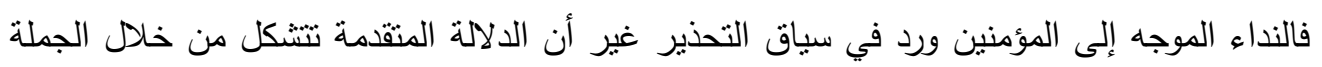

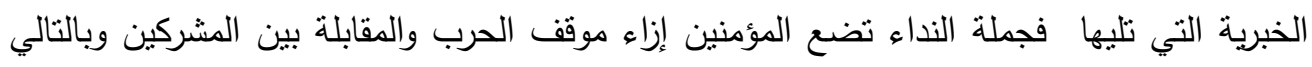

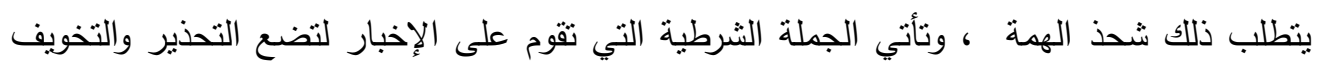

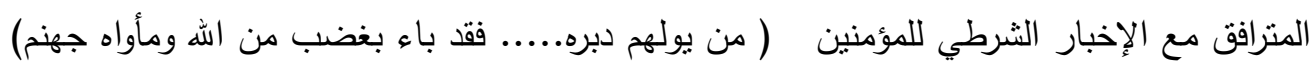
وهل غير ذلك من تحذير أكبر من غضب الإن تعالى والوقوع في النار.

وقد يتعاضد الارشاد والتوجيه مع التحفيز ليشكلان دلالة مزدوجة والسياق هو الذي يقوم بتأطيرها والعمل على إقامة مفاصلها الدلالية ، ويكون السياق مؤلف من الجملة الخبرية التي تتآزر

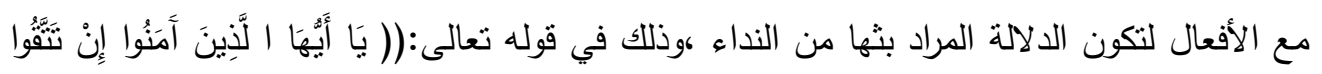

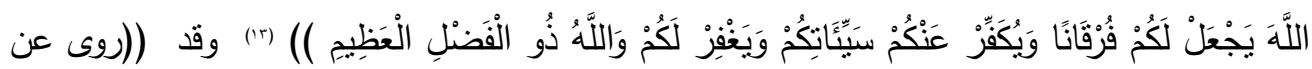

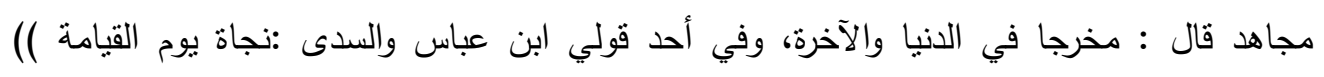

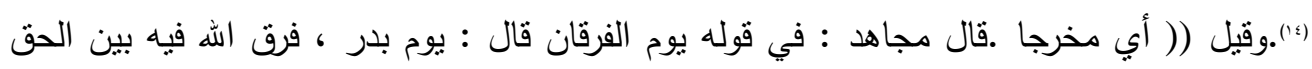

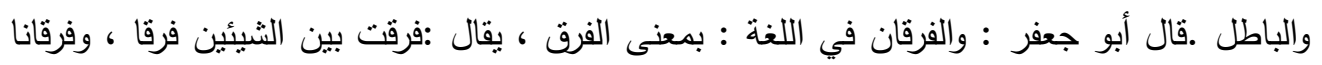


والنص في دلالته المجازية خارج إلى الارشاد والتوجيه ، بيد أن الدلالة لا تتأطر في أداة ا لنداء

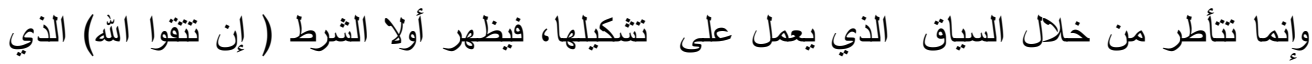

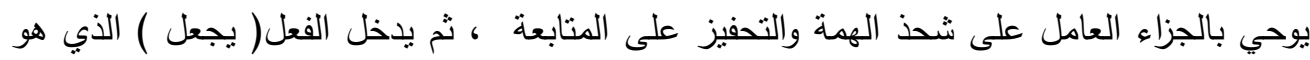

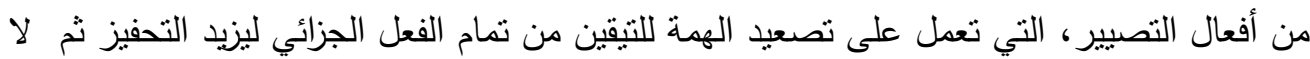

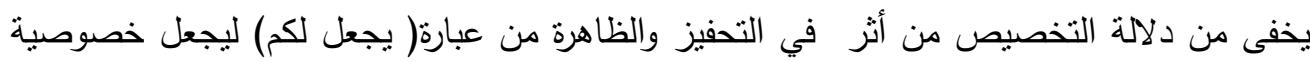

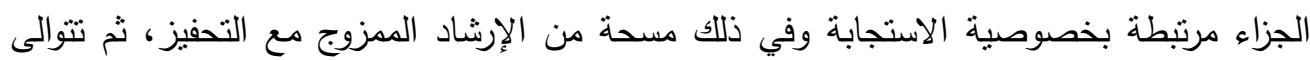

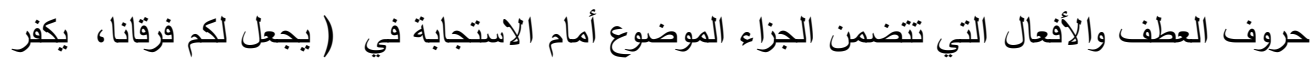
سيئاتكم ، يغفر لكم ) ثم تدخل الجملة الخبرية ( ولله ذو فضل عظيم ) لتضع لحد الأعلى للتحفيز فوراء كل المحفزات المنقدمة عطاء الله الأعلى الذي قد تكون الجملة الخبرية حاملة لـهـ له.

وللسياق السببي التفسيري الذي يبين ماهية النداء والأطر التي قامت وراءه كما في قوله تعالى :

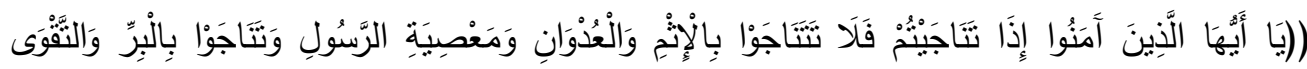

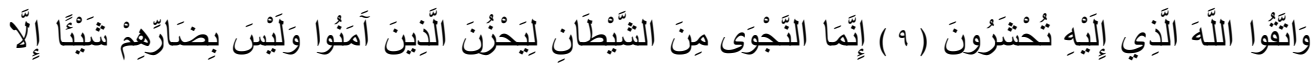

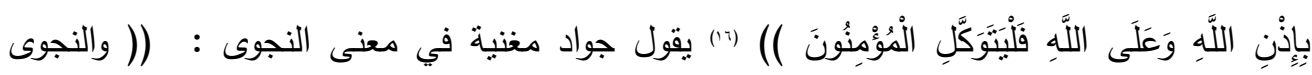

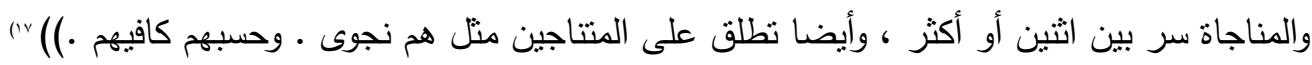

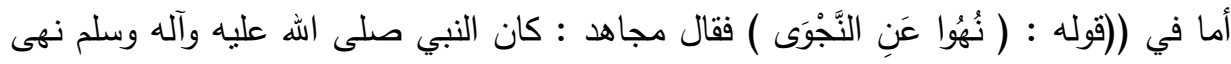

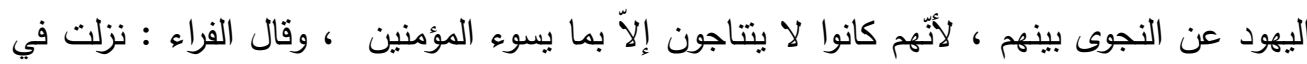

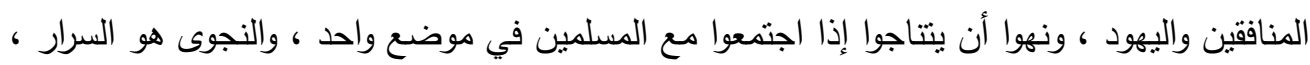

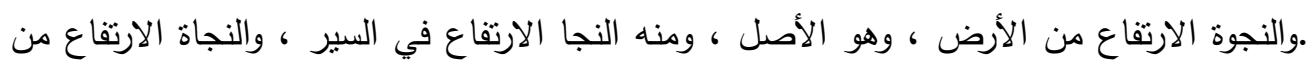

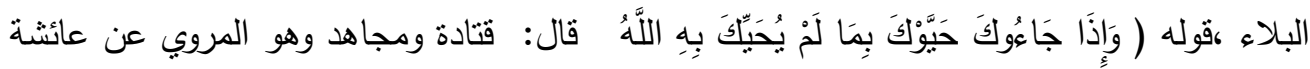

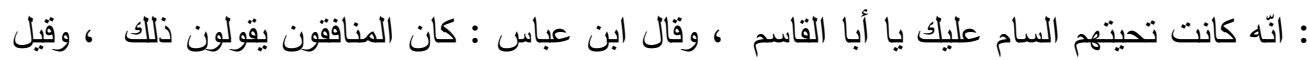

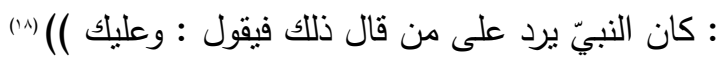

فالآية القرآنبة داخلة في باب الإرشاد والتوجيه الذي يتم من خلاله توجيه المؤمنين إلى ما ينفعهم ( البر والثقوى) وينهاهم عن الذي يسؤهم ( التتاجي بالآثم والعدوان) ويظهر الارشاد في إطاره 
السببي الإقناعي من خلال السياق الخبري الذي يحمل الثيء المتقدم(إنما النجوى من الثيطان ليحزن

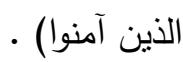

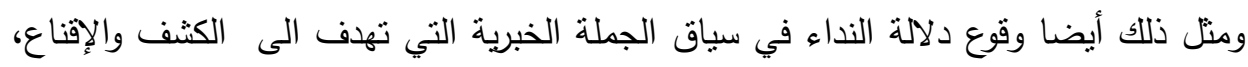

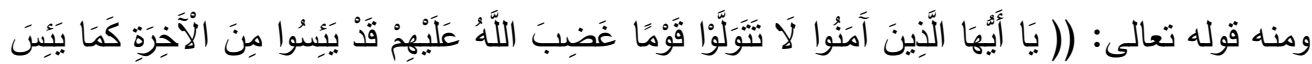

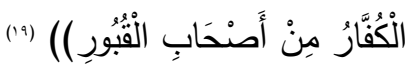

فالنداء خارج في دلالته الى الإرشاد الممزوج بالتحذير من تولية المشركين على المؤمنين

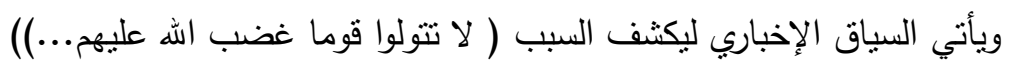

وقد تتعاضد الجملة الاستقهامية مع الجملة الخبرية في تكوين دلالة النداء القرآني كما في قوله

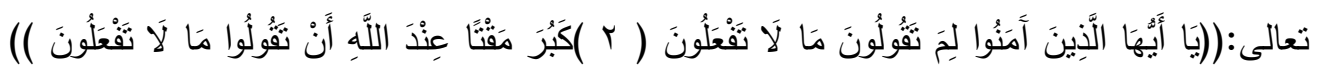

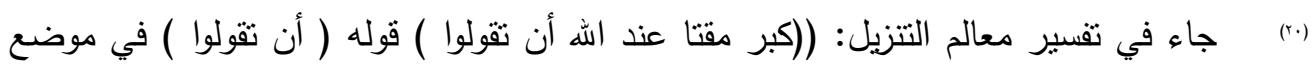

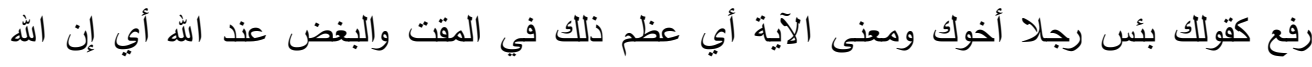

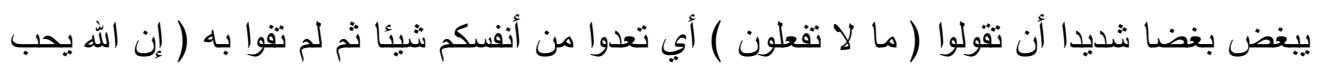

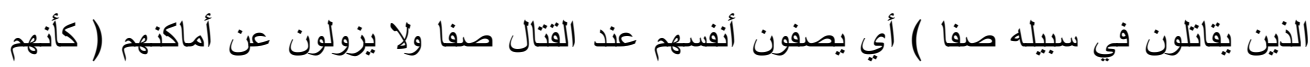
بنيان مرصوص ) قد رصّ بعضه ببعض أي ألزق بعضه ببعض وأحكم فليس فيه فرجة ولا خلل

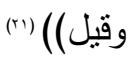

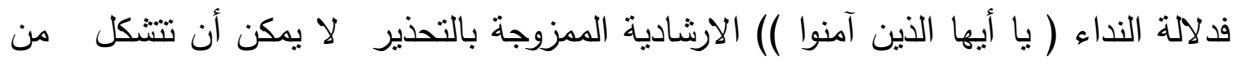

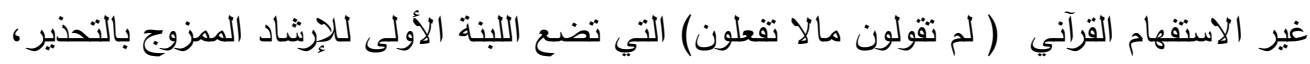

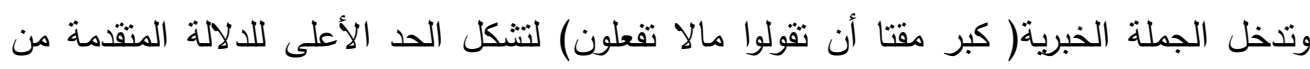

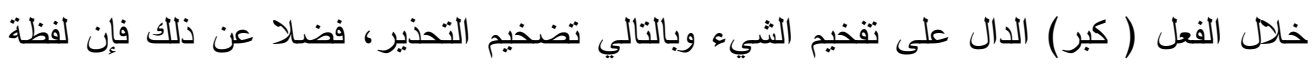

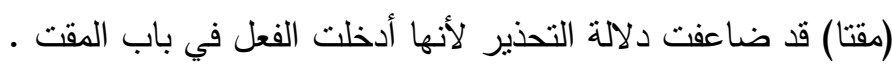

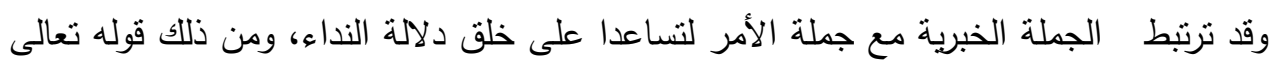

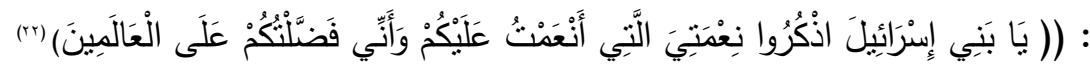




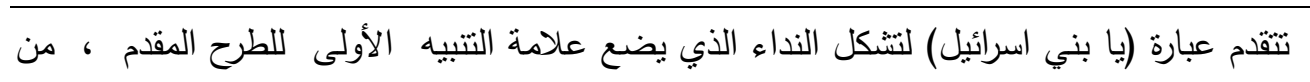

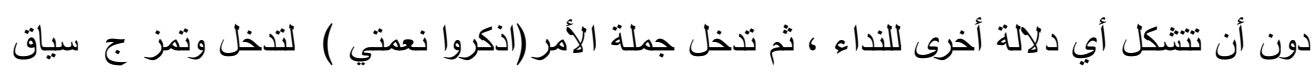

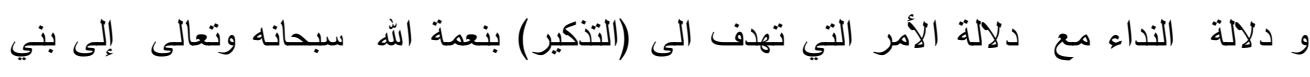

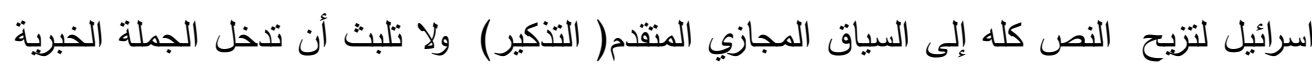

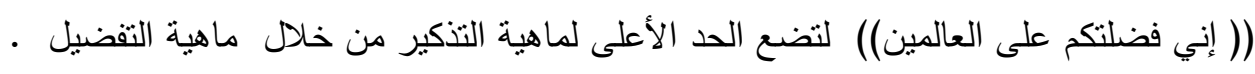
وقد يأني النداء في إطار جملة الأمر فلا يسنطيع النداء ولا جملة الأمر في خلق الإطار

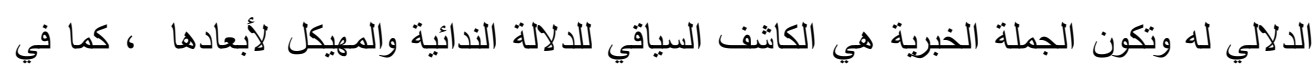

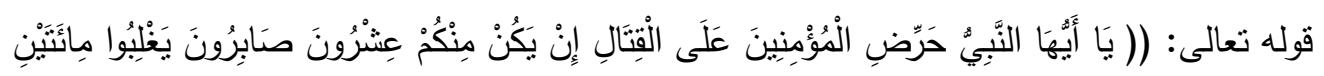

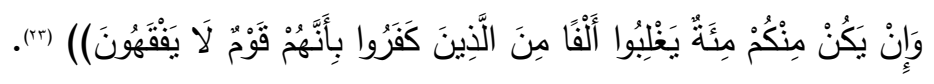

والمعروف أن ((التحريض والتحضيض والتحريص بمعنى واحد وهو الترغيب والحثّ على التى

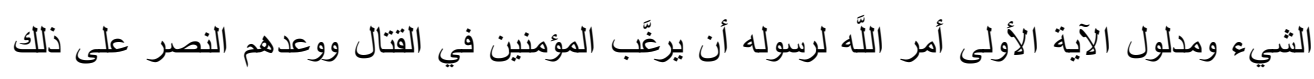

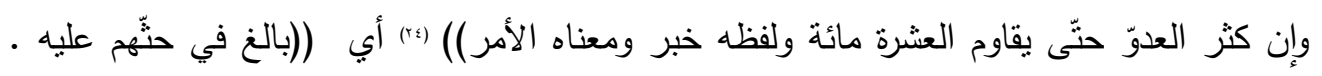

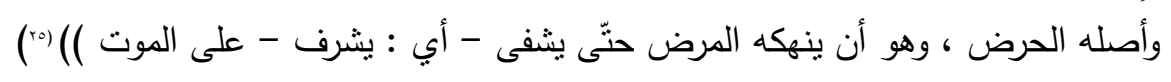

وقد يكون للجمل الاستفهامية الاثر الواضح في السياق الذي تتشكل على أساسه دلالة

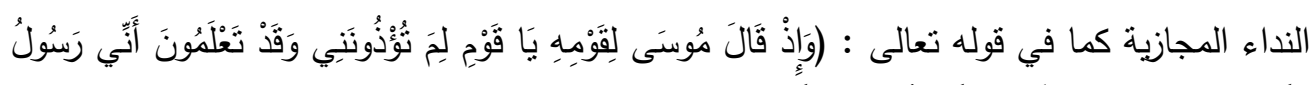

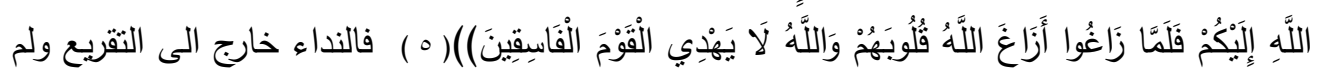

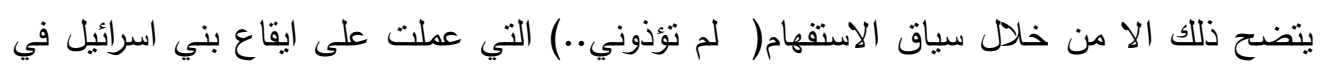

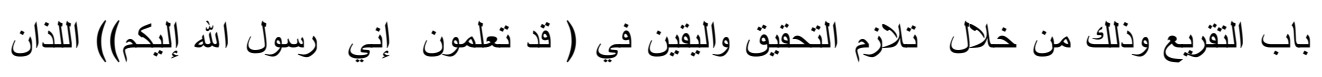

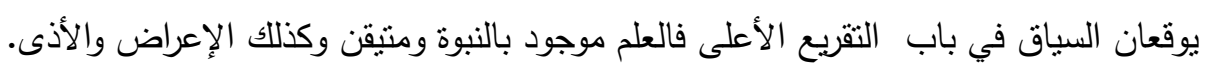




\section{اللفظ وأثره في خروج النداء المجازي}

قبل الدخول في ماهية الموضوع لابد من الاشارة إلى أنّ اللفظ قد ورد كثيرا في النداء عن

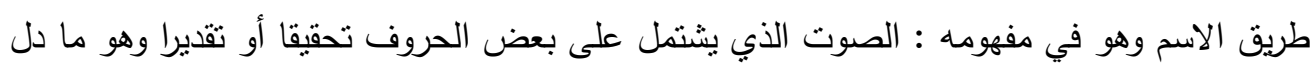

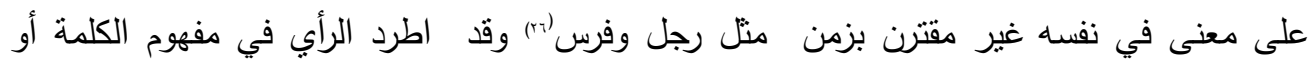

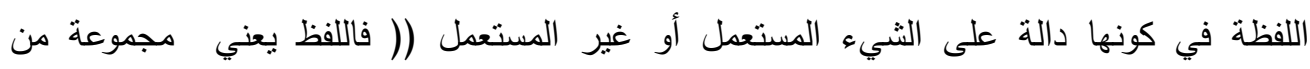

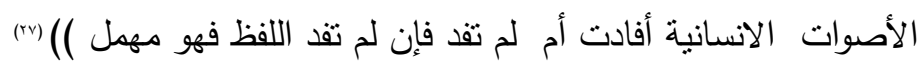

وأولا ننطرق إلى اللفظ حسب ما تقدم له من معنى ،إذ نرى أنّ هناك نأثبرا كبيرا للفظ وهذا

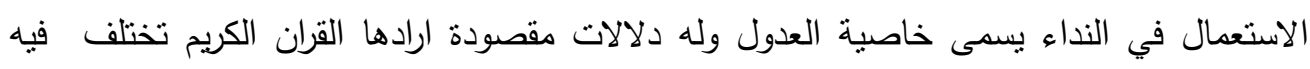

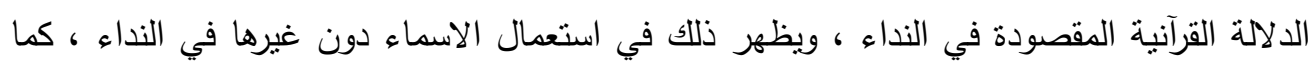

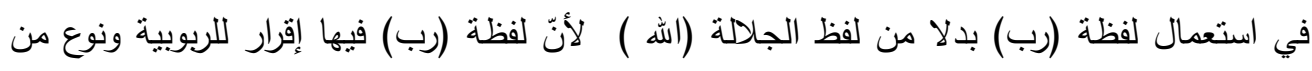

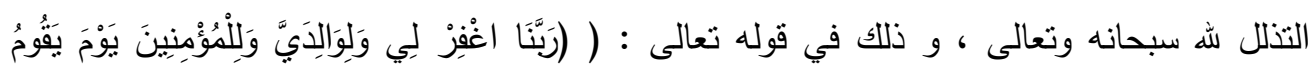

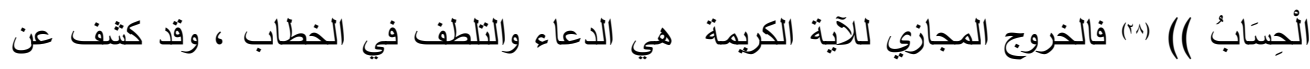

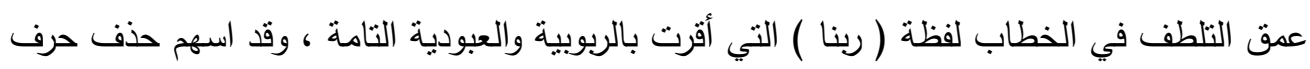

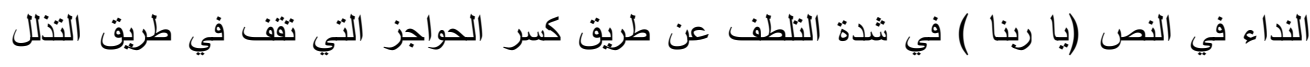

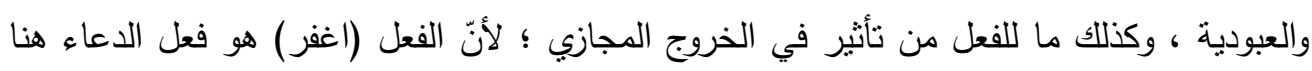

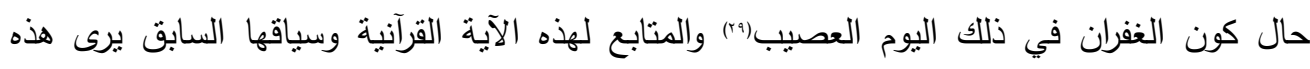

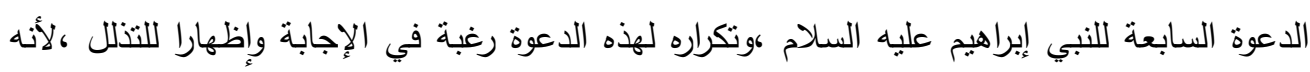
ختم دعاءه الخاشع بالاستغفار لله ولوالديه وللمؤمنين جميعا (.).

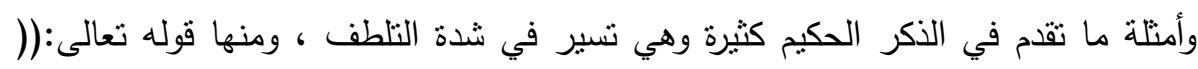

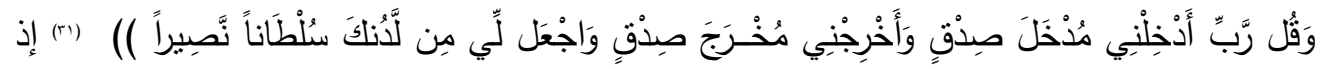

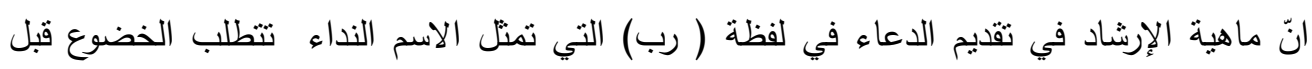

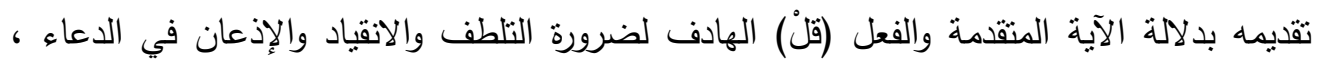

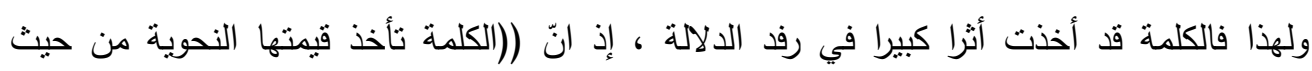
موقعها في البنية العميقة )) (rr) و قد يصل التلطف في الدعاء مداه لأهمية اللفظ فيه وأثره الأكبر

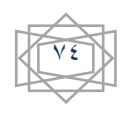




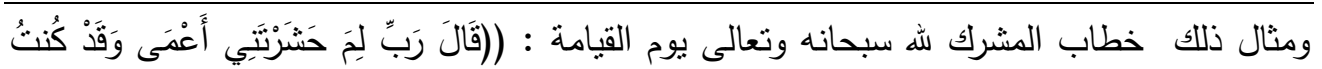

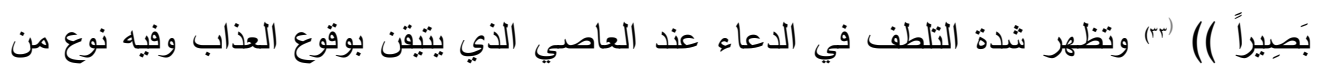

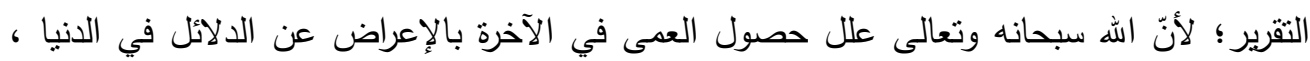

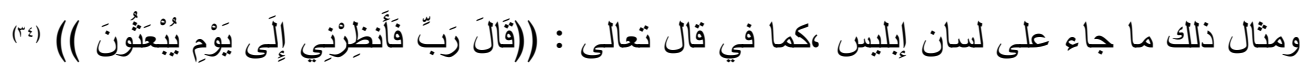

إذ نرى التلطف في الدعاء منطلقا من حذف أداة النداء (يا رب ) ( من الربوبية ) وكأنّ إبليس

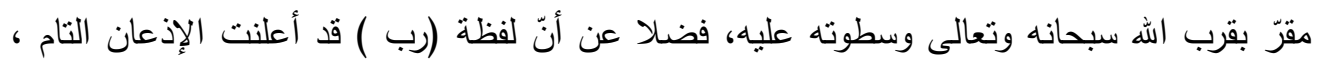

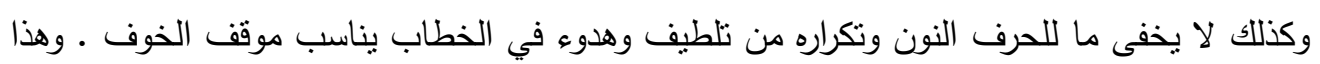

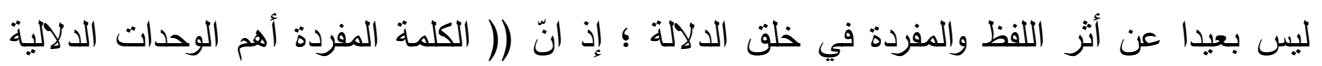

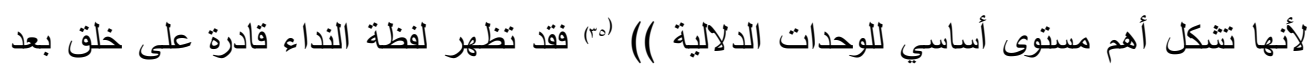

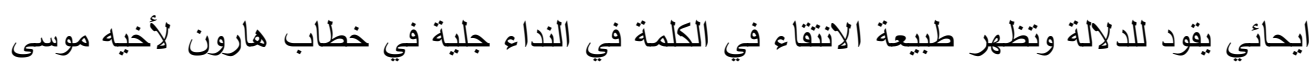

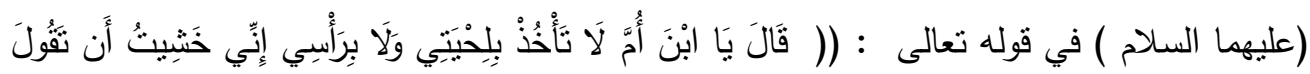

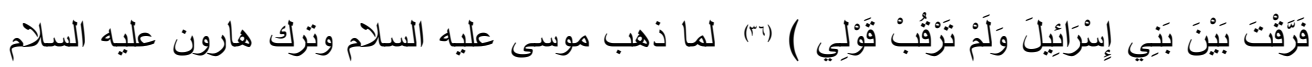

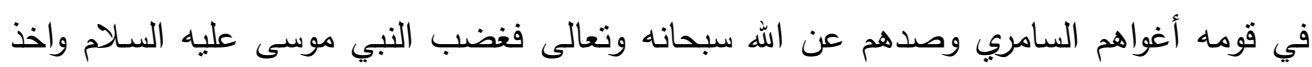

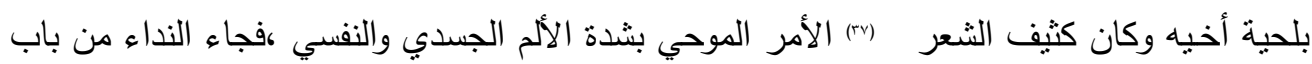

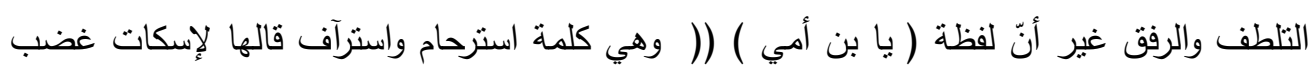

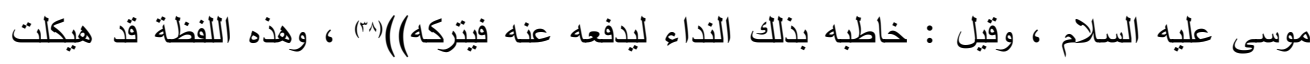

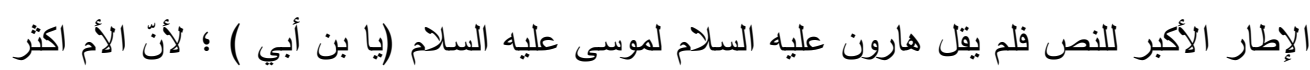

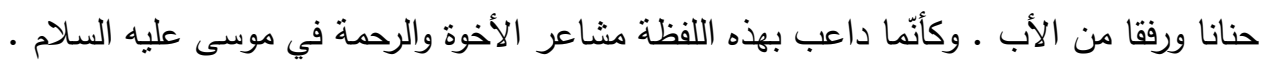
وقد يكون للفظة أثرا كبيرا في رصد الدلالة الندائية المراد إيصالها، ومن ذلك دلالة الاستغاثة

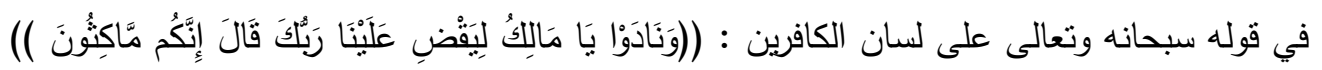
(99) إنّ دلالة تمني الموت والانعدام قد أصبحت طلب المجرمين في جهنم ليتخلصوا من العذاب الأليم

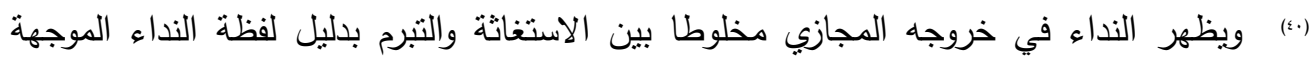

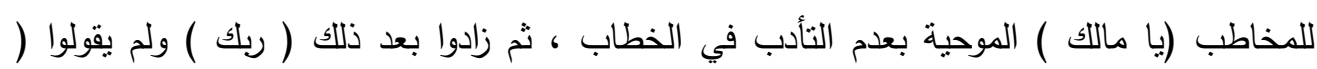

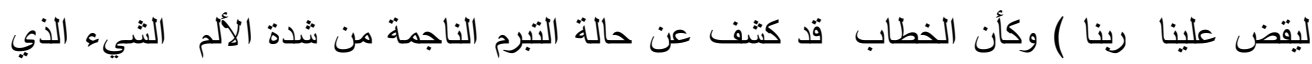

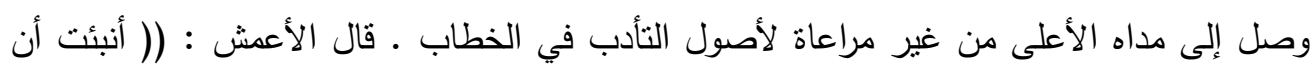

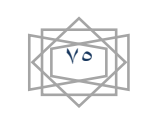


بين دعائهم وبين إجابة مالك إياهم إلف عام ، قال أدعوا ربكم فلا أحد خير من ربكم )(1) وهذا القول حالة التبرم الناجمة من طول اننظار الاجابة مع المكوث في العذاب.

وللفظ القرآني أثز فاعل في اسقاط الجو النفسي الذي توحي به دلالة النداء ، فمثلا: في في التياء

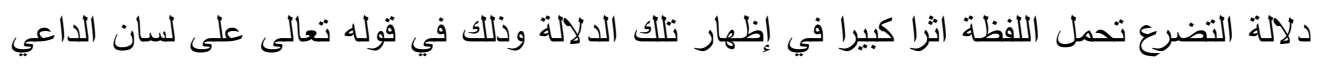

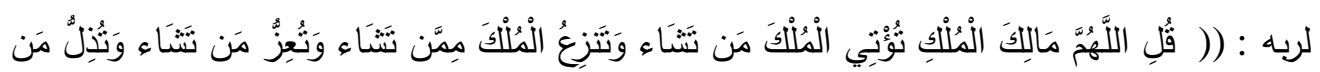

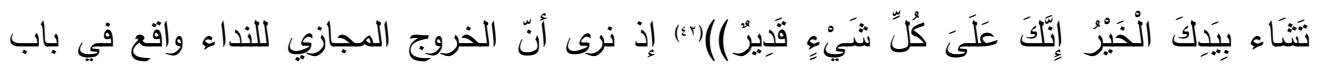

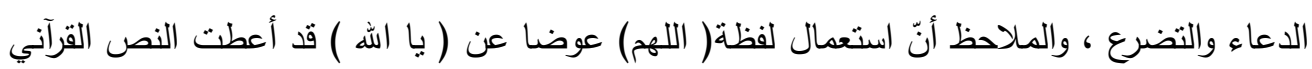

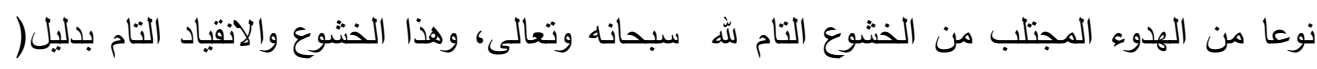
تؤتي الملك من نتشاء) قد اسهم في تفعيل التضرع وتصعيد مستواه ليتتاسب وعظمة الخالق سبحانه وتعالى.

وقد يخرج النداء القرآني للتقريع فيكون للفظ الأثر الكبير في ايقاع تلك الدلالة ومثال ذللك

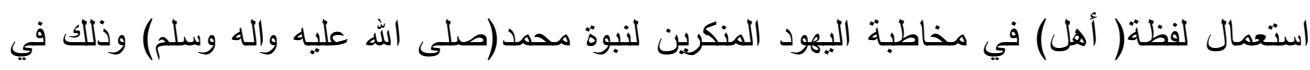

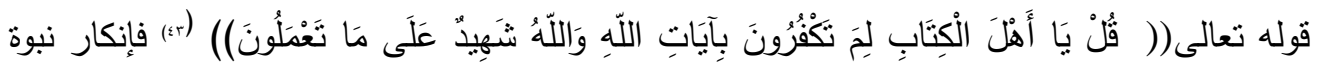

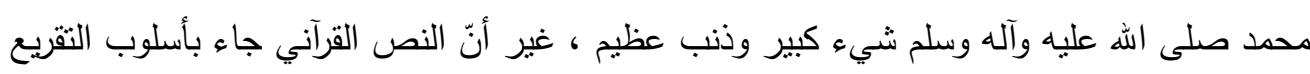

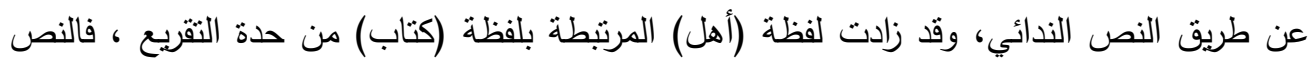

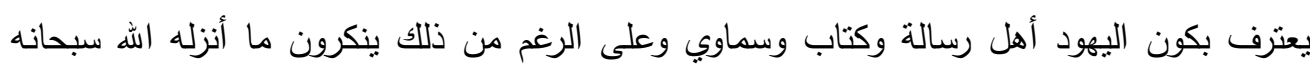

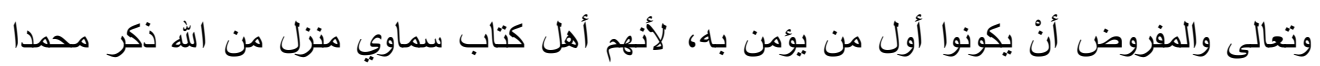
صلى الله عليه واله وسلم ونبوته.

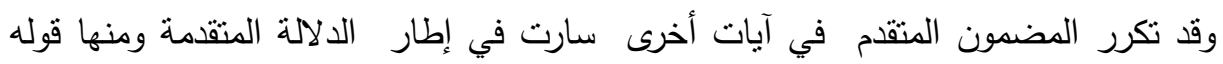

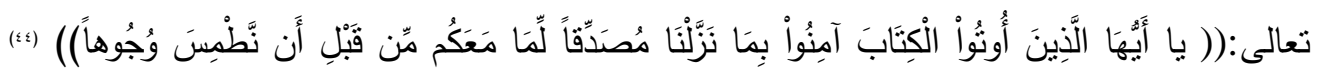

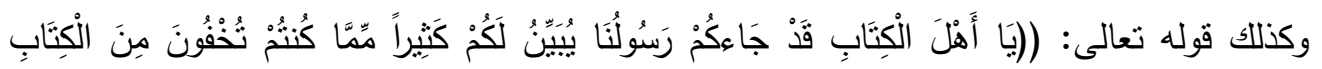

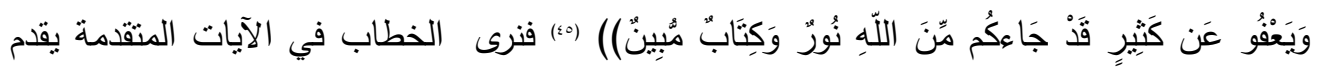

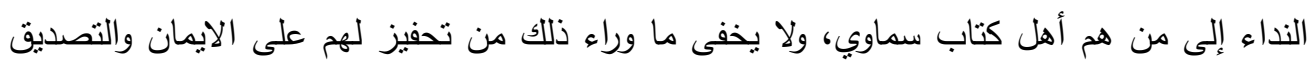
بنبوة محمد صلى الله عليه واله وسلم لهل

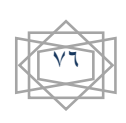


ويأتي الاسم في النداء قادرا على جلب الجانب الاقناعي أو الجانب الارشادي أو التحفيزي

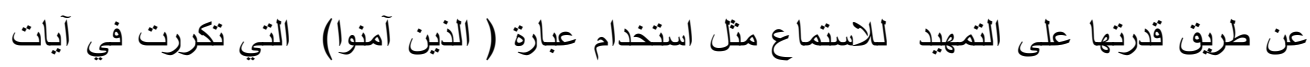

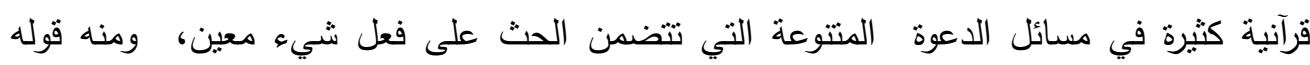

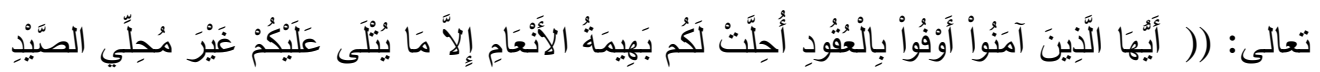

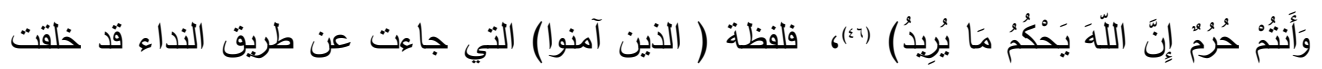

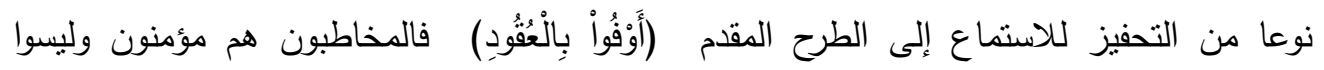

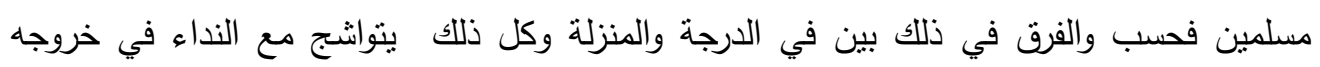

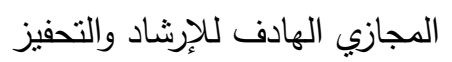

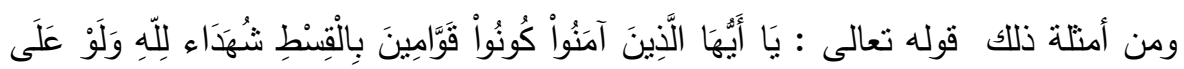

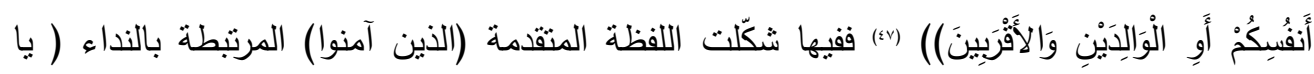

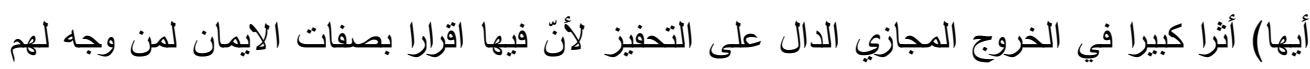

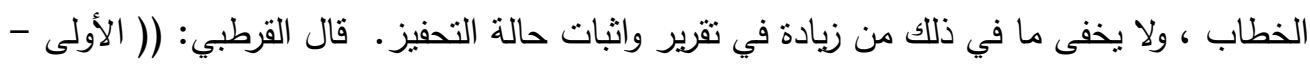

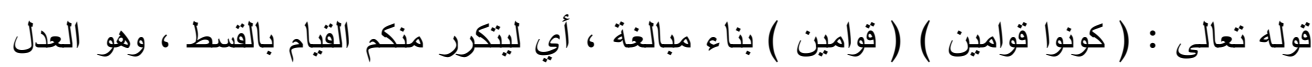

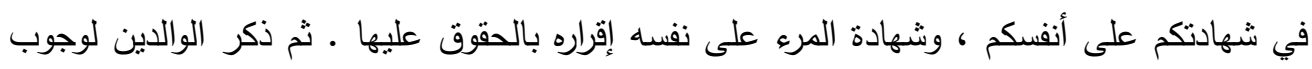

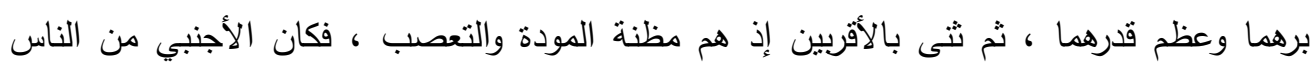

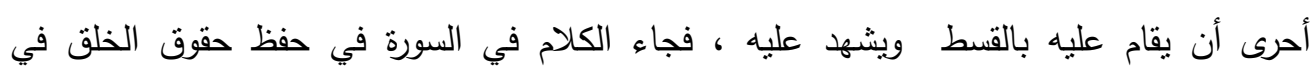

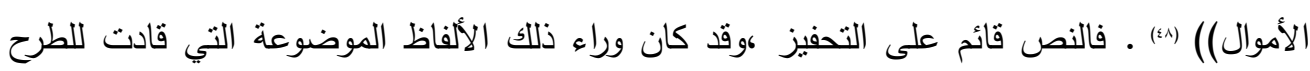
المقدم للمتلقي.

وقد تعمل العبارة المتقدمة ( يا أيها الذين آمنوا) · على الزيادة في التحذير كقوله تعالى:

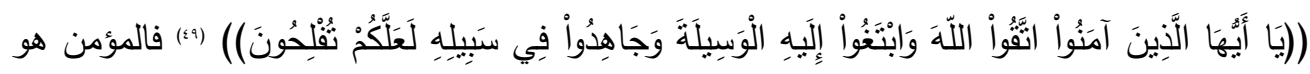
أولى الناس بنقوى الله ؛ لأن الناس تمضي بسيرته وتقبس عليه.

وقد يأتي الاسم ( المؤمنون) في باب التحذير المشوب بالمنع الداخل في النداء كقوله

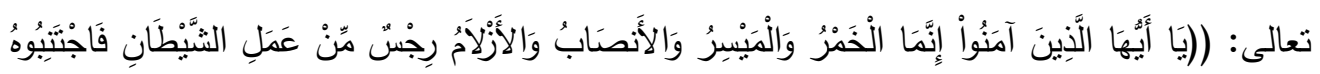

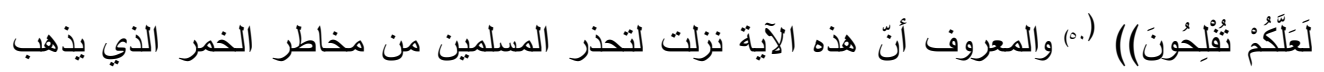


العقل، وقد جاءت عبارة (الذين آهنوا) لتناغم مشاعر الايمان التي تعلو بصاحبها عن شرب الخمر الذي يغيب العقل ويحط من قيمة الانسان.

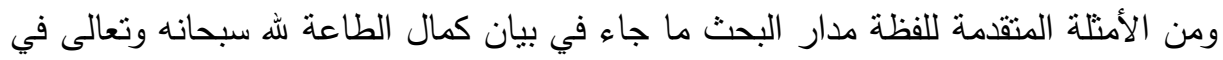

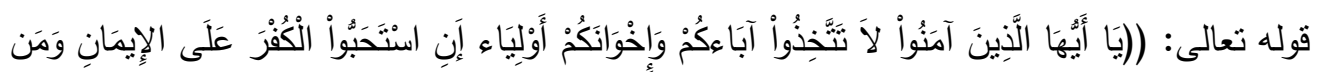

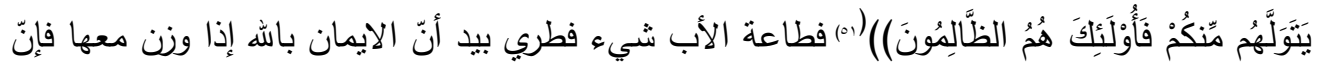

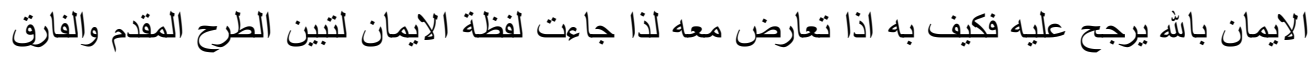

وتأتي اللفظة المتقدمة في النداء للتأكيد على الركن المهم في الدين وهو الصلاة التي تتضمن

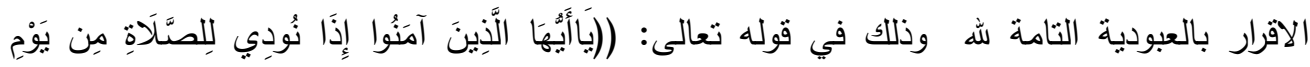

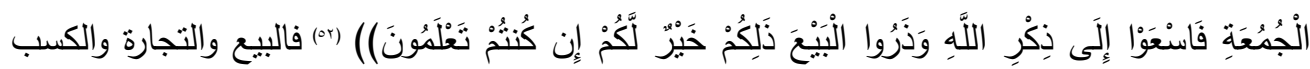

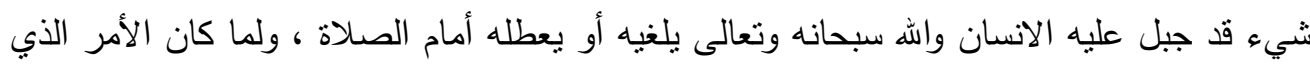

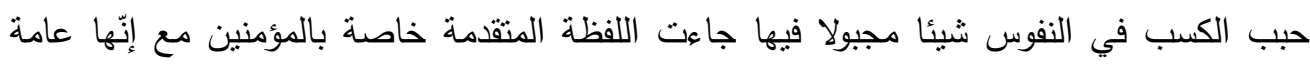
وذلك لتحفيز المسلمين جميعهم على المداومة على الصلاة.

ويظهر كذلك أثز اللفظة في حرف السياق المجازي للنداء نحو الثيء المراد تقديمه ، بمعنى آخر فإنّ فيها اختبارية مقصودة وظهر ذلك في لفظة ( قوم )المستخدمة في النداء كثيرا و ومنها قوله

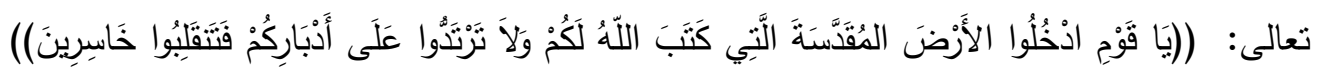

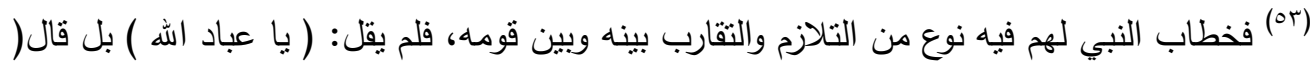
يا قوم ) وكأنما خاطبهم الملزومية التي ترجعه لهم من قبل النبوة وبعدها وهي أنّهم أهله وعثيرته.

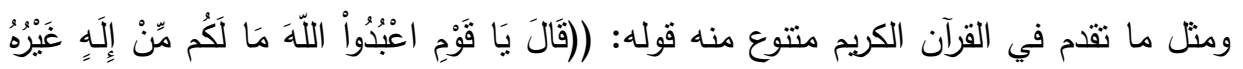

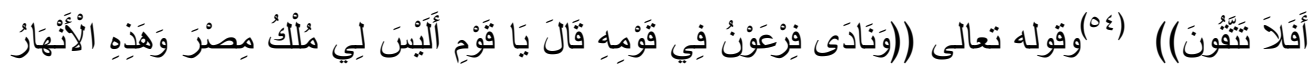

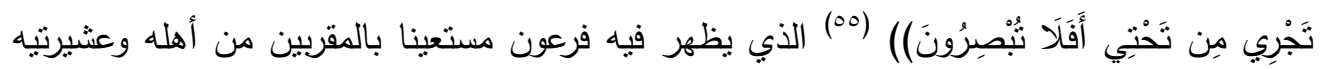
ليتبتوا ويقروا له بالملك. تئي

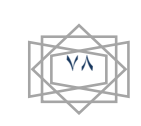


وللاسم أثر كبير في قوة التحذير المنبثق من النداء القرآني عن طريق تجسيد عظمة المخاطب

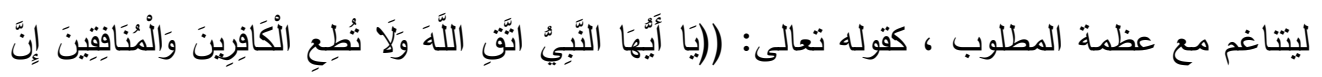

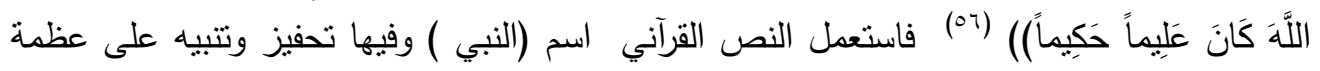
الرسول صلى الله عليه واله وسلم وعظمة الأمر المنوط به بدليل عبارة( اتق الله) وذللك ليتم التركيز

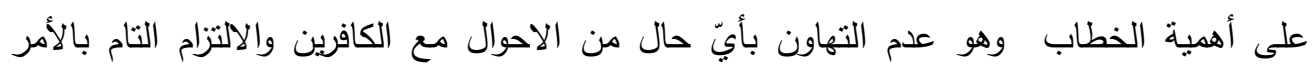
الالهي.

ونرى أن" ذكر أسماء الأنبياء في النداء قد يصبح له أثره في تبيين ماهية الخروج المجازي وقد

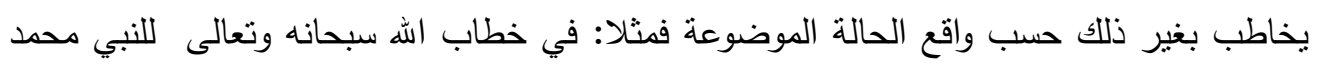

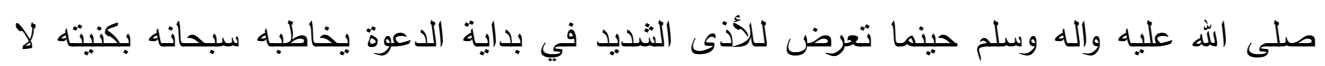

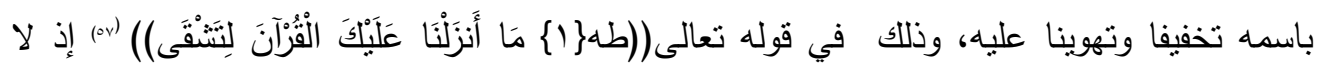
يخفى ما في الاسم (طه) من هدوء ونغمية تنتاسب وحالة التهوين والترويح عن النبي صلى الهه عليه

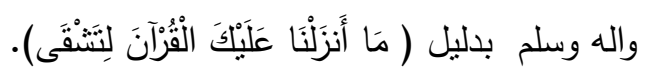

ويظهر أثز الخروج المجازي في مخاطبة النبي موسى ( عليه السلام ) قومه في قوله تعالى:

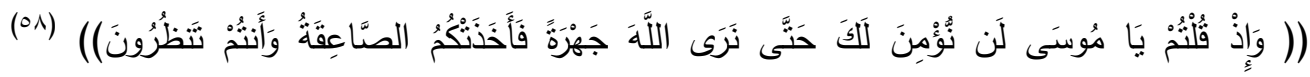

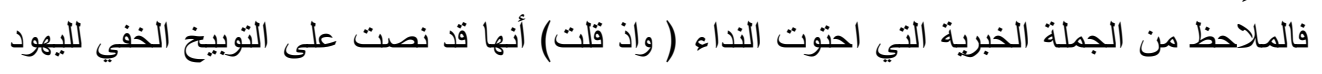

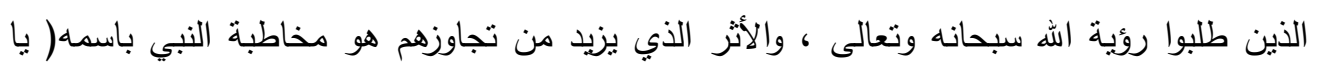

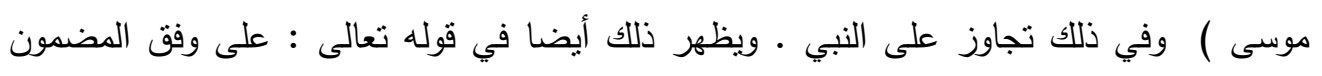

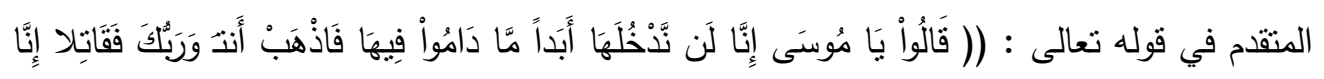

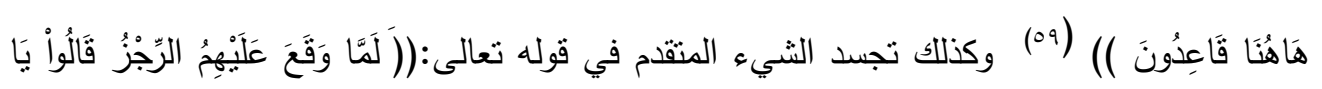

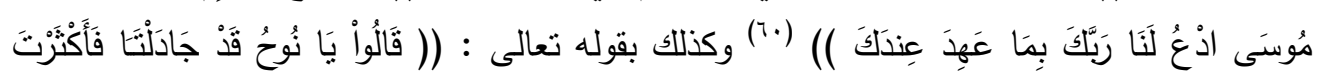

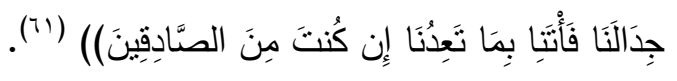

ولو نظرنا إلى خطاب اله للأنبياء نجده قد يستعطل اسم النبي غير ذاكر لنبوته إذا نطلب

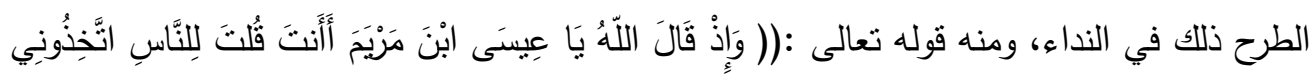

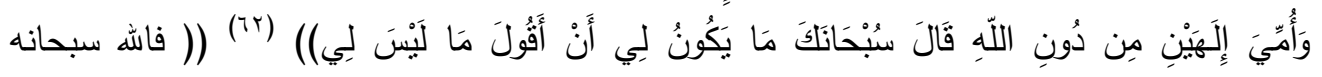


يخاطب عيسى عليه السلام باسمه ( با عيسى) ولم يذكر النبوة وجعله انسانا مجردا لأنّ النص واقف

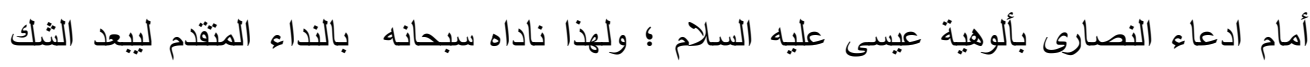

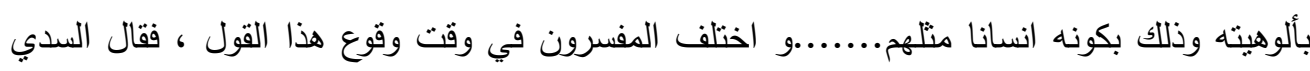

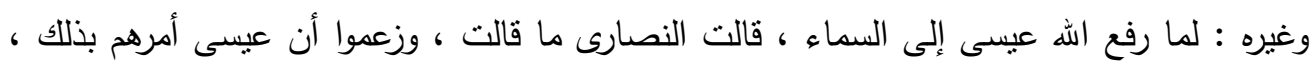

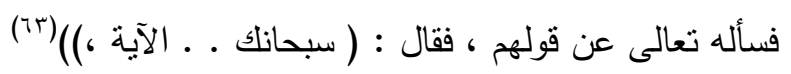

وقد تأني الرقة في الخطاب بالاسم المستعمل في النداء والذي يتتاسب ويكثف عن علاقة

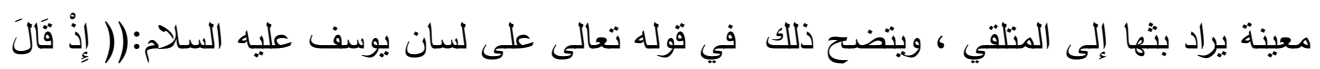

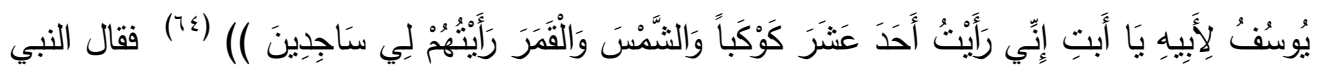

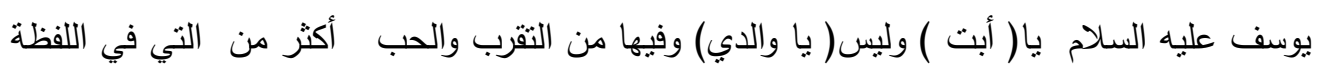

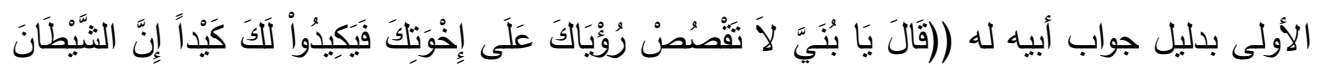

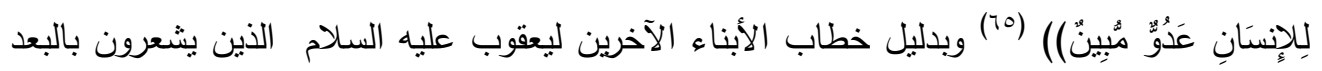

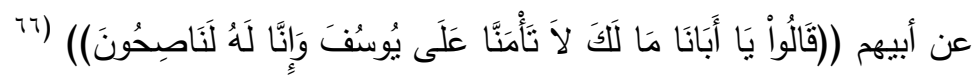

وجاءت في النداء القرآني ألفاظ قد كثفت عن الخروج المجازي قبل أوانه بل وعملت على ألى

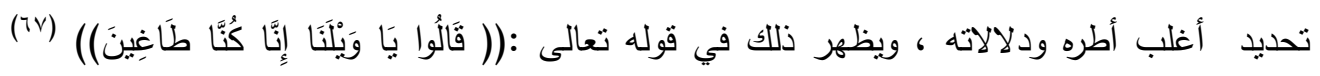
فلفظة ( با ويلنا) قد كثفت عن الندم الثديد الذي اعترى من قصر بحقوق الهه ولم يؤمن به وانتهى فئى أجله ولا لفظة اقدر على تثكيل الندم أكثر من اللفظة المتقدمة.

ويظهر أثز اللفظة الواحدة في كثف مدلولات الخروج الجازي للاستفهام كذلك في قوله

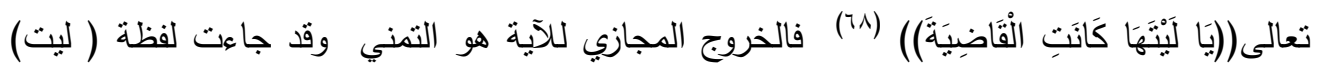
لتكثف عن ذلك المضمون وتؤطره بأوضح صوره.

ويشارك الاسم في النداء الخروج المجازي ودلالاته ، وتعمل على خلق أطرها ويظهر ذللك في

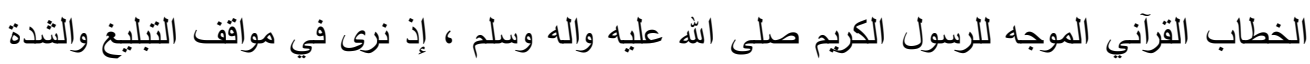

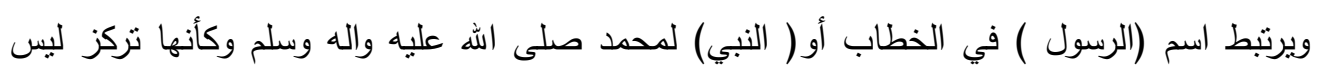

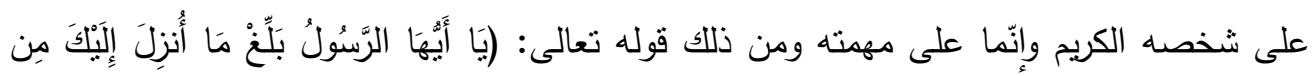

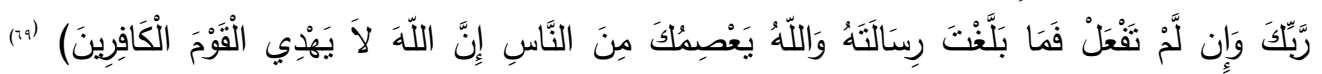




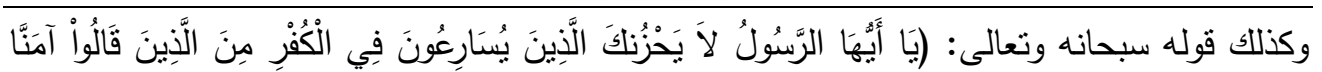

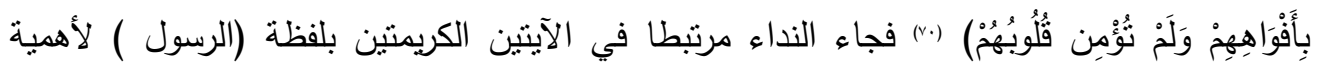

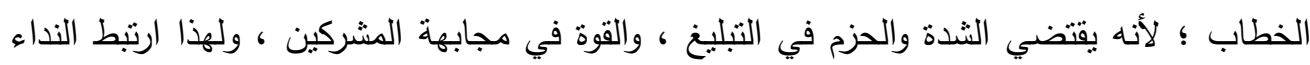

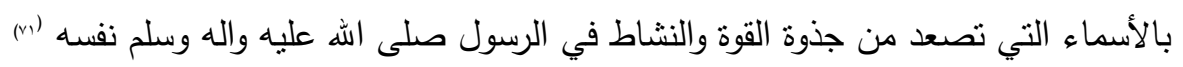

ويقف أمام ما تقدم خطاب النبي بالاسم بلفظة (طه )في الخروج المجازي الموحي بالترحم

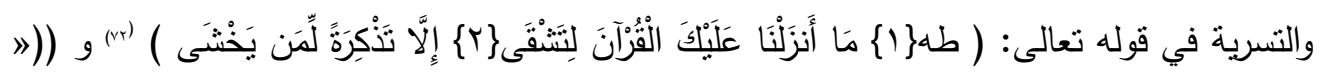

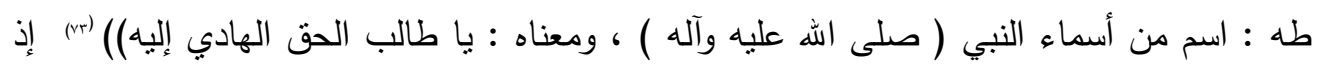

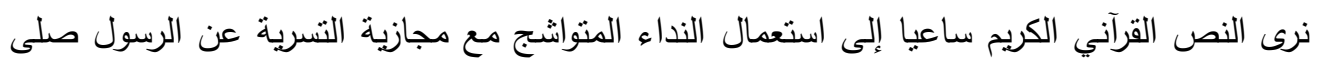

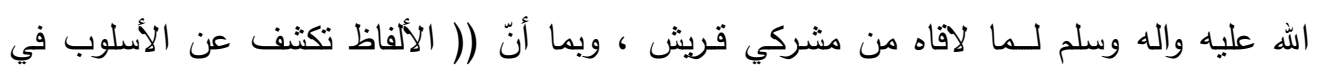

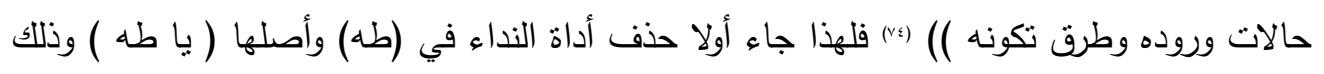

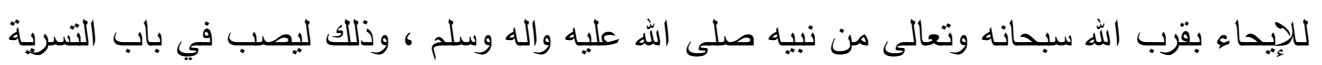

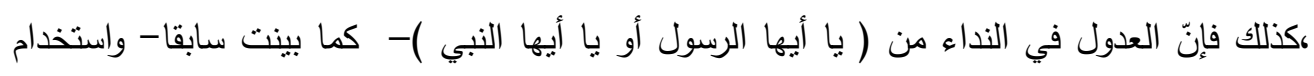

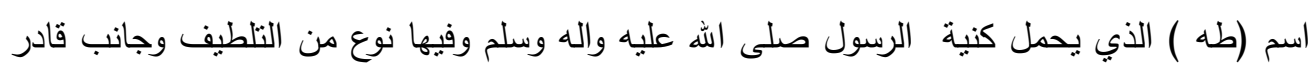
على النسرية ؛ لما فيها من حرف مد قادر على إطالة الوقفة ، ولهذا يكون الاسم المنقدمة قد أسهم إسهاما فاعلا في الخروج المجازي للنداء.

ويظهر للفظ أثر كبير في رصد دلالة الخروج المجازي للنداء ، فبعد أن تقدم خطاب التسرية

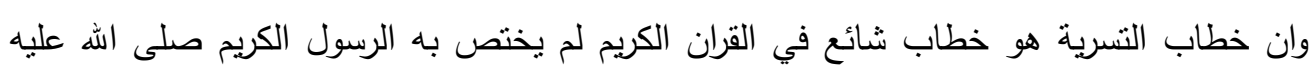

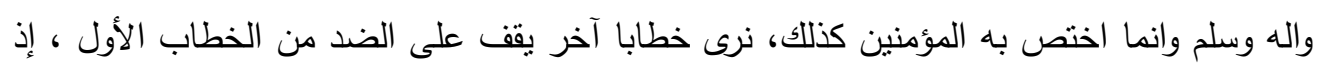

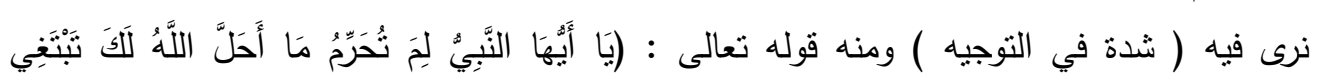

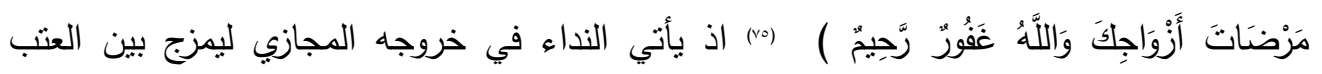

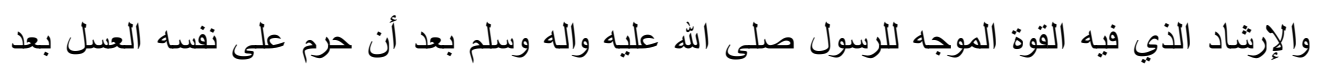

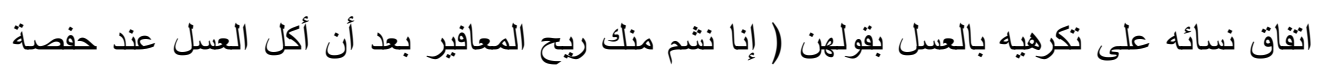

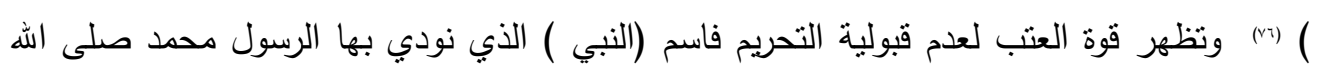

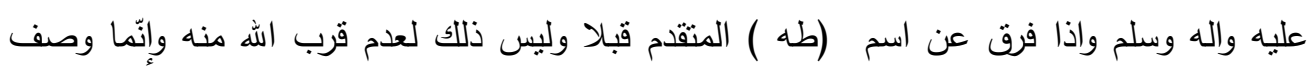

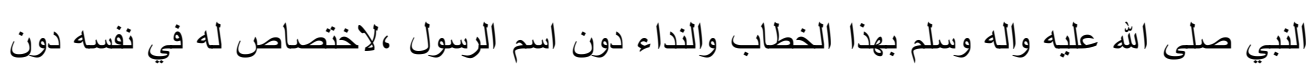

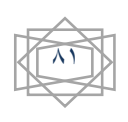


غيره، وكذلك لأهمية الأمر ولضرورة التتبيه عليه و على شدة اللوم(( وهو خطاب مشوب بعتاب

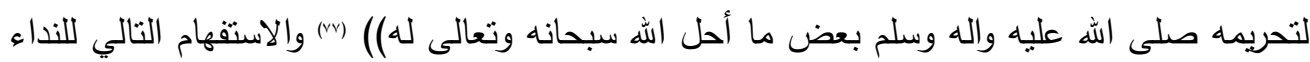

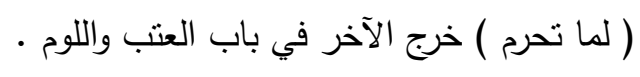

وقد يكون النداء موجها من الله سبحانه وتعالى للبشر ويختلف من وجه لآخر ، فمرة (با أيها

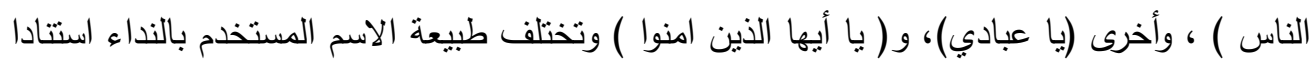

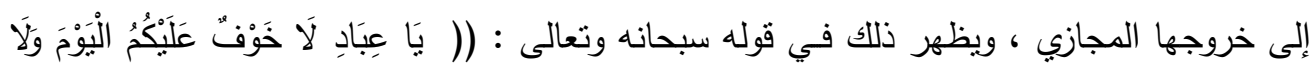

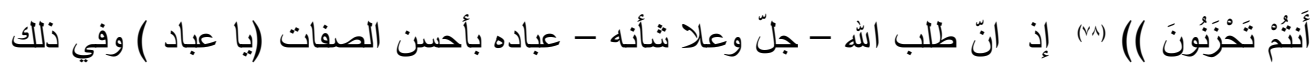

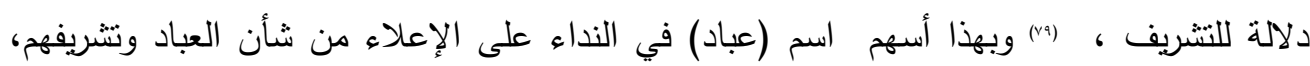

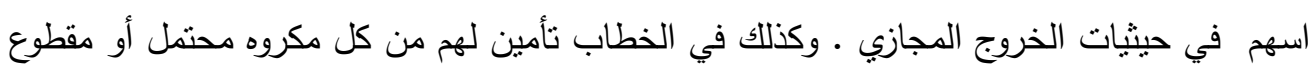

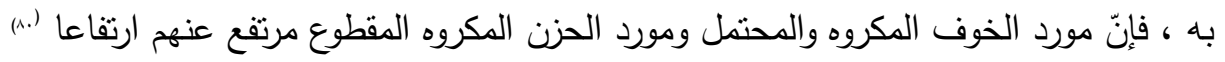

وقد يأتي اسم (عبادي ) في النداء في غير ذلك ، فيأتي مرنبطا بالتأنيب للانين عصوا الله

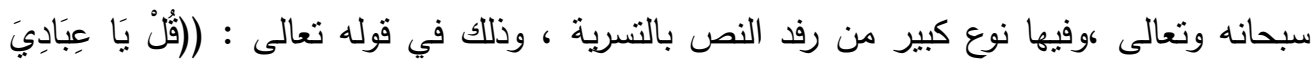

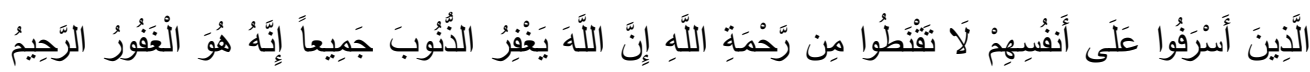

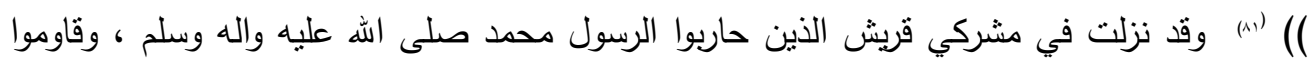

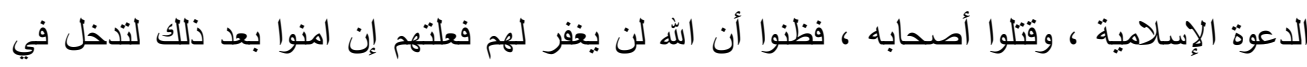

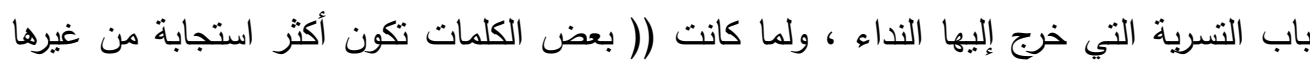

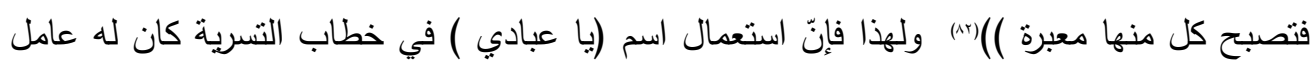

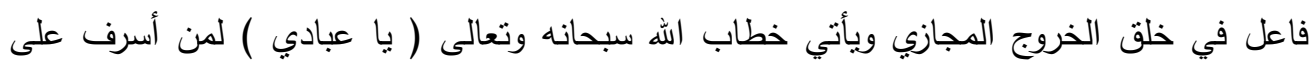
نفسه كرسائل تطمين وتسرية تتحاور وتتدمج مع الخروج المجازي( (وأمره أن يدعوهم من قبله ويناديانيهم بلفظة يا عبادي وفيه تذكير بحجة اله سبحانه وتعالى على دعوتهم إلى عبادتهم لهم إلى استجابة

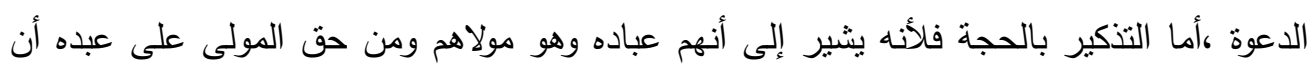

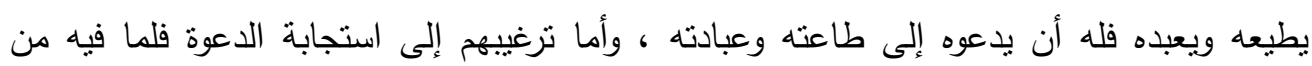

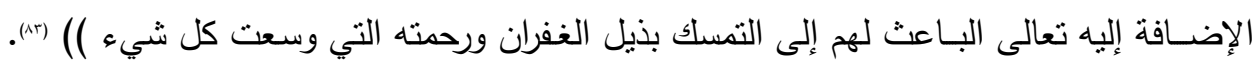


وييدو التركيز على اللفظة وانتقائها ماثلا في ورود الياء في آخرها (عبادي ) لما لحرف المد التهاء

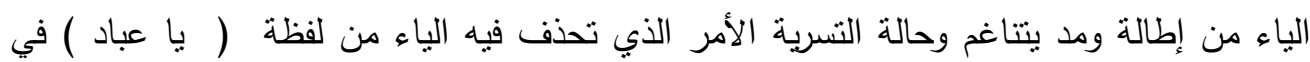

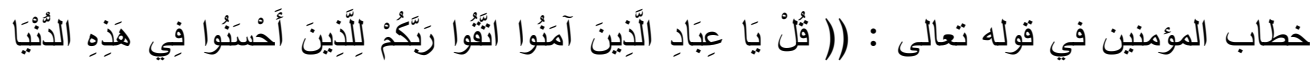

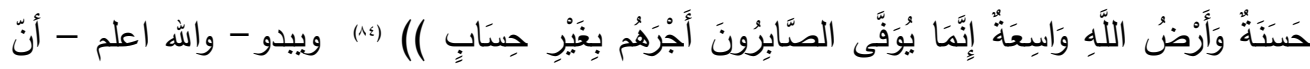

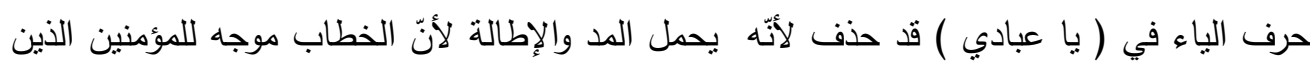

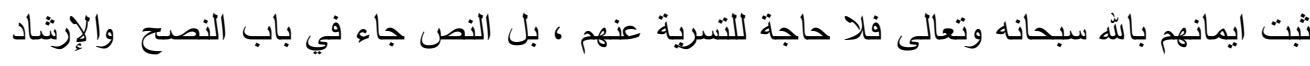

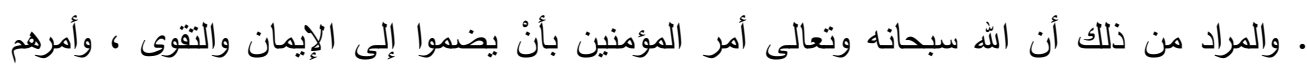

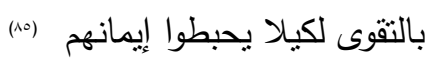

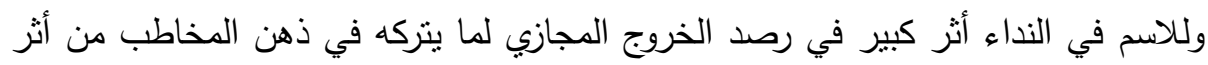

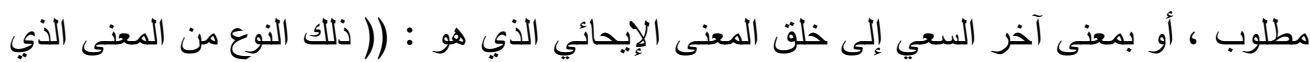

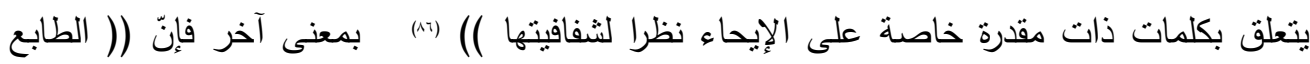

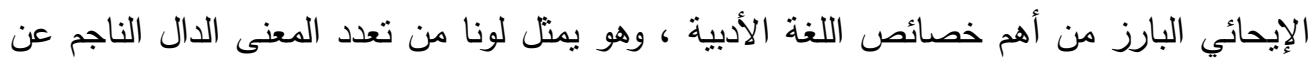

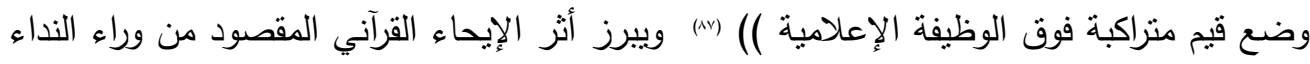

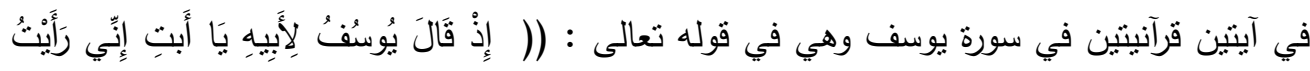

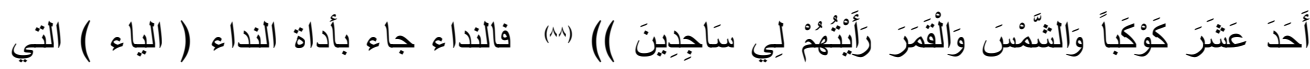

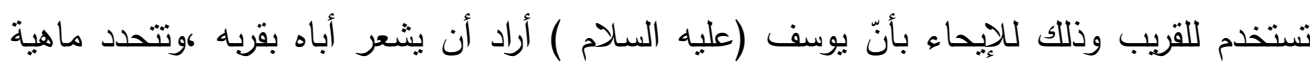

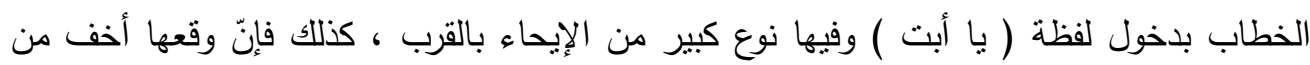

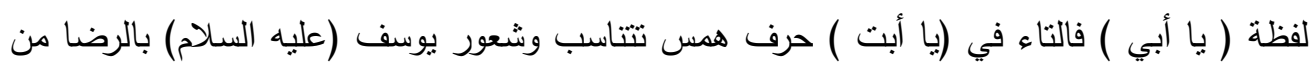
أبيه وقربه منه .

ونرى في مكان آخر خطاب إخوة يوسف (عليه السلام ) لأبيهم ورغبتهم بخداعه والتحايل في

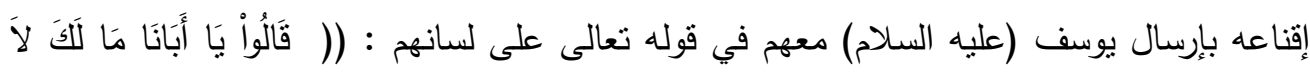

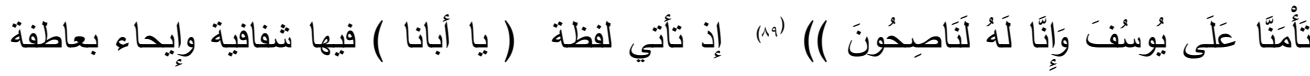

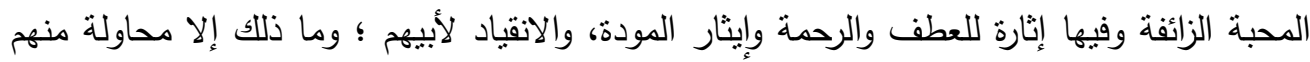

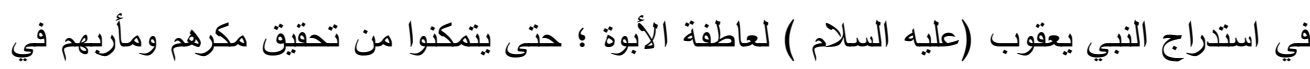

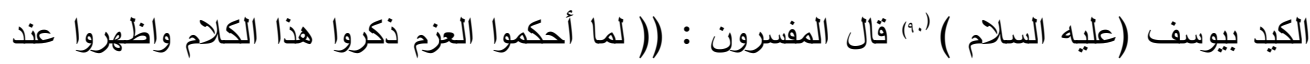


أبيهم أنهم في غاية المحبة ليوسف ،وفي غاية الثفقة عليه ، ليستنزلوه عن رأيه في تخوفه منهم كأنهم قالوا: لم تخافنا عليه ونحن نحبه ونريد الخير به ) (1).

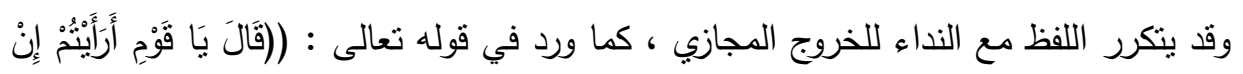

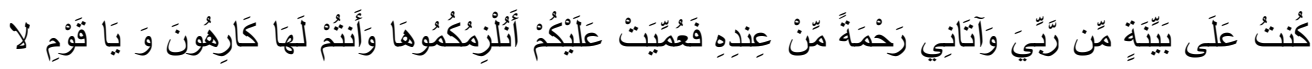

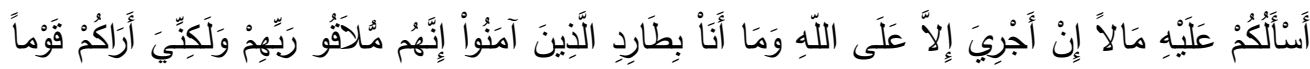

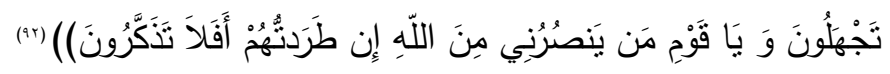

إنّ النص القرآني المتقدم ما هو إلا جواب من النبي نوح عليه السلام إلى قومه ، وإتمام الحجة

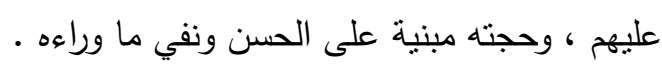

وقد أبدع الخالق سبحانه وتعالى بآياته الكريمة في تقرير حجته عليه السلام في جوابهم فقطعت

$$
\text { حجتهم فصلا فصلا }
$$

وقد جاءت الحجج مبذوءة بالخطاب مع تكرار اللفظ في قوله نعالى : (با قوم ) وهو خطاب في

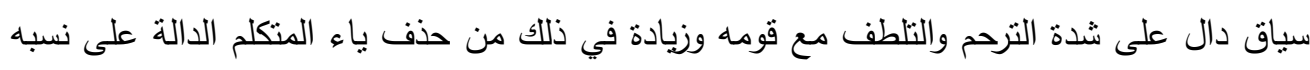

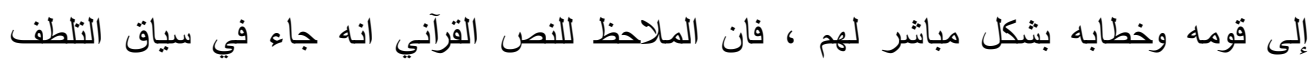

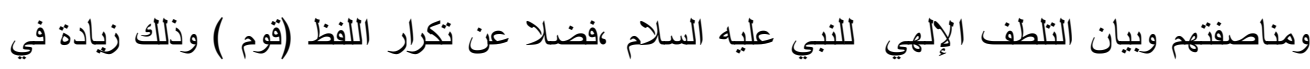

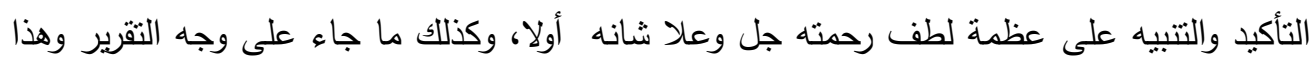

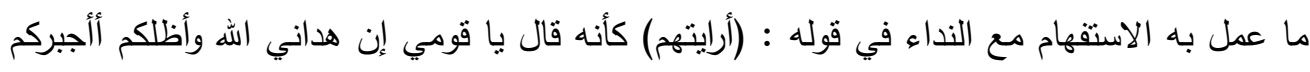

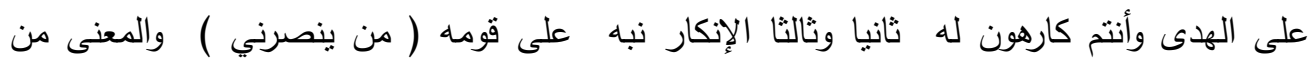

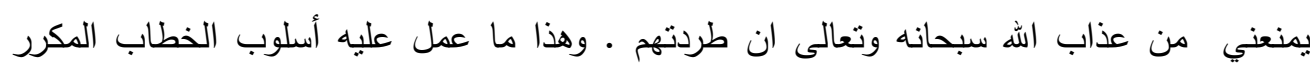

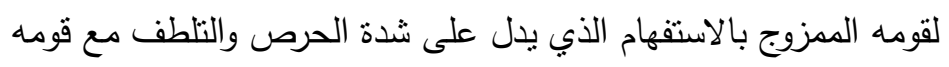




\section{الفعل وأثره في خروج النداء المجازي}

معروف أنّ الفعل هو حدث مقترن بزمان ،والفعل في النداء يأتي حاملا لأثر كبير في رفد دلالة الخروج المجازي ، ولا عجب في ذلك فالفعل هو جزء من كل البناء وإنّ (( كل مفردة في القران

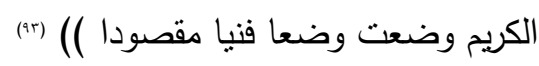

وقد يكون السياق مكونا من فعل الأمر المتكرر الذي يضع السياق الذي يخرج اليه أسلوب

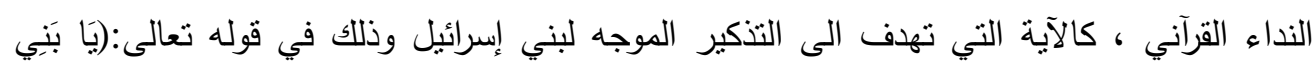

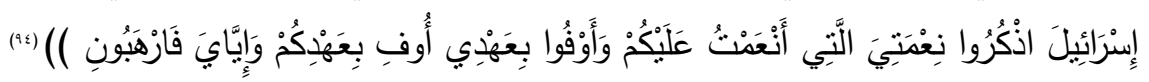

قال الطبرسي:(( لما عم سبحانه جميع خلقه بالخطاب ، وذكر لهم الحجج على توحيده ، وعدد

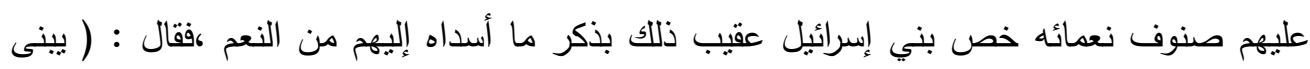

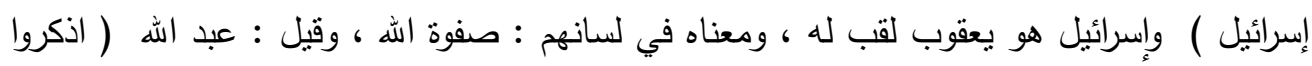

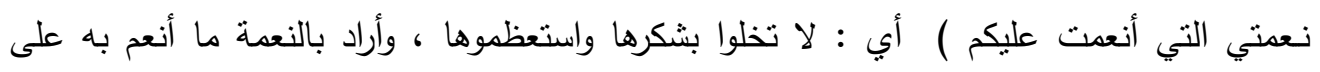

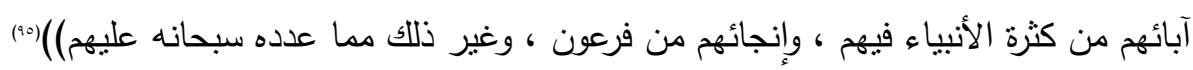

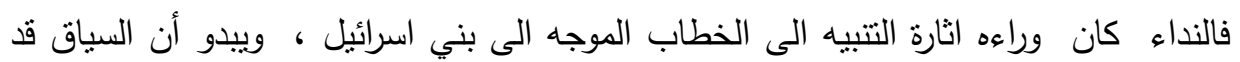

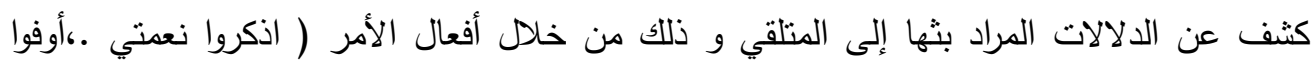

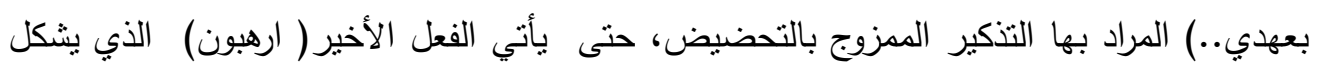

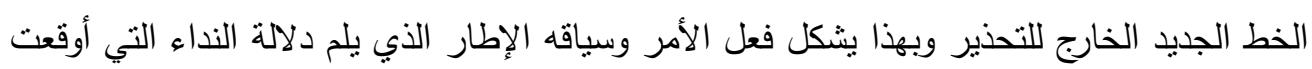
التتبيه المراد بثنها الى المنلقي.

وللفعل أثز كبير في إسباغ الصبغة المجازية على النداء ، ويظهر ذلك في انتقائية اختيار الفعل

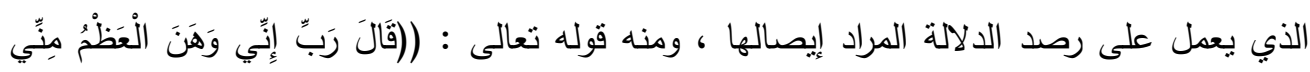

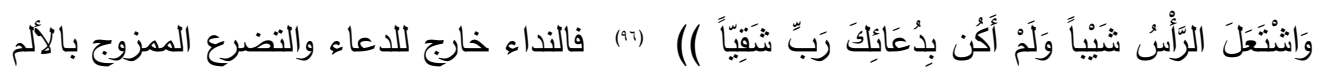
انطلاقا من حذف أداة النداء (رب ) للمسارعة وشدة الضيق الموحي بحال النبي زكريا (عليه السلام )

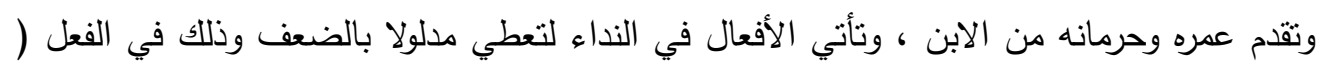

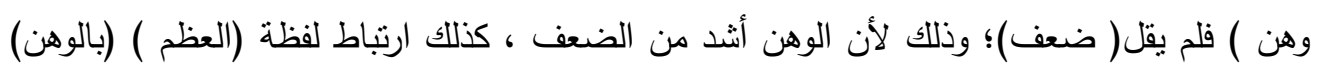


أعطى النداء مزيدا من الألم ، فلم يقل : (وهن الجسم ) وإنّما ( وهن العظم ) ذلك ليعطي المبالغة

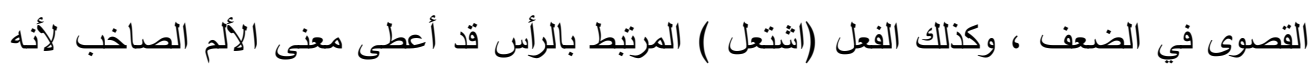

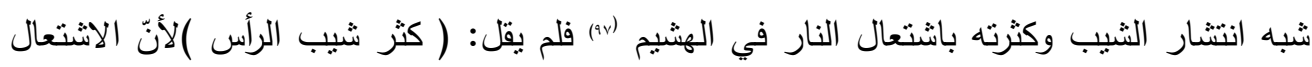

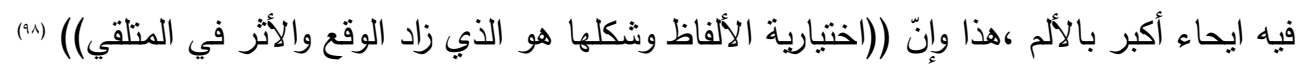
وللافعال انز كبير ليس في تجسيد الخروج المجازي وانما في رصد الدلالة الزمنية المتحركة

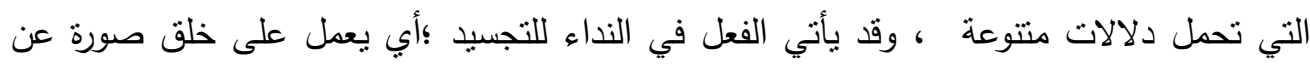

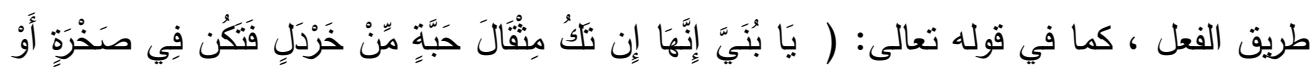

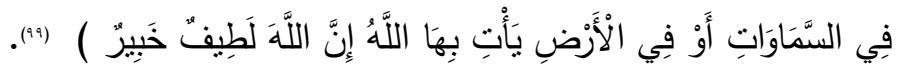

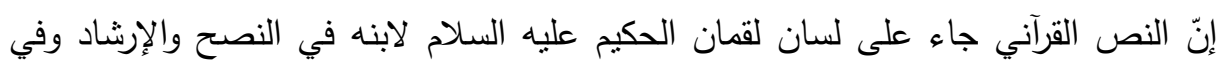

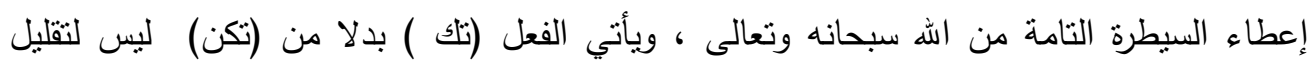

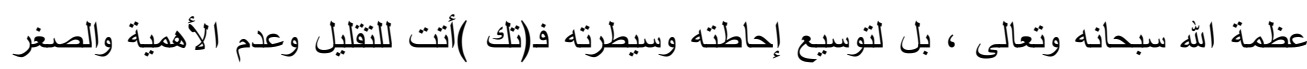

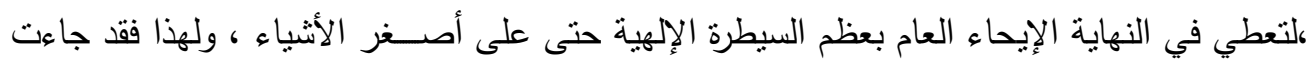

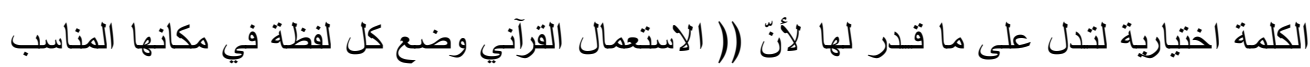

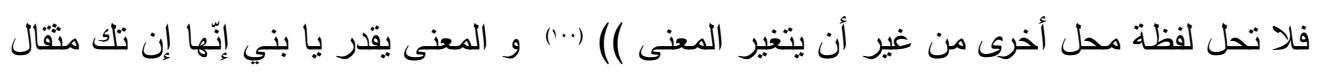

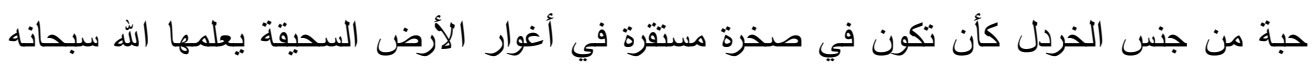
وتعالى وهذا دليل على عظمته سبحانه وتعالى (...)

وقد يخرج النداء القرآني للتحذير ، فيكون للفعل أثرا واضحا في توجيه الدلالة ، ولفت

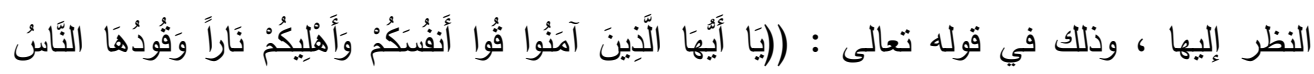

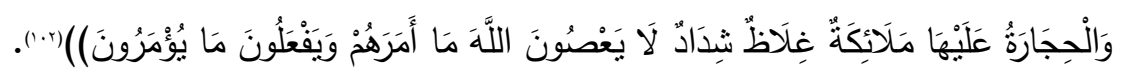

فالنداء في الآية المتقدمة خرج للتخويف والتهويل ، ويظهر أنّ الفعل ( قو) قد أسهر في

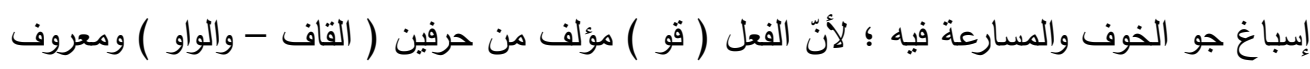

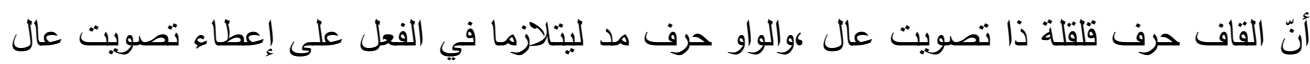

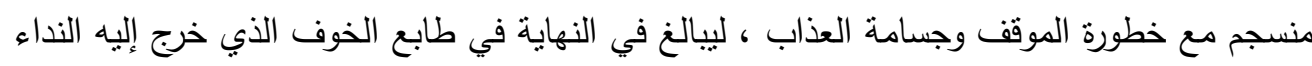
المجازي وهو أمر من الوقاية بمعنى حفظ الثيء مما يؤذيه ويضره (F.r.) 
وقد يكون الفعل هو الأوحد في توجيه الدلالة في النداء ، كما في خروج النص القرآني للتحذير

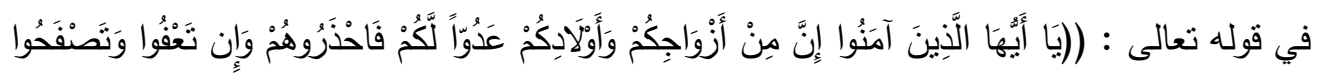

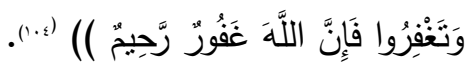

إذ يأتي الفعل (احذروهم ) ليعطي التصريح بالتحذير وليخرج النص كلّه على وفق ذلك ؛لأن

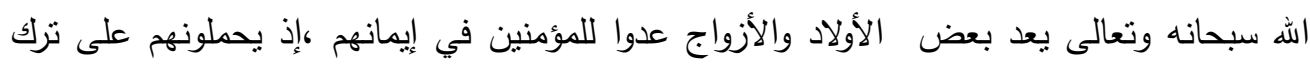
الإيمان باله ،أو ترك بعض بعض الأعمال الصالحة وهذا عمل على بيان دلالته الفعل (1.0)

وللأفعال أنز كبير في النداء ومن ذلك قوله تعالى في مخاطبة بني إسرائيل في إطار النصح

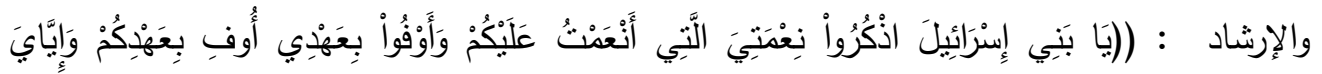

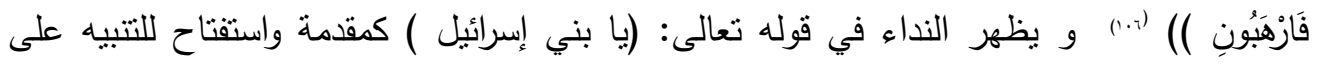
الثيء المقدم ليدخل النص في باب الإرشاد والتوجيه التي ظهرت جليه من خلال الأفعال ( اذكروا -

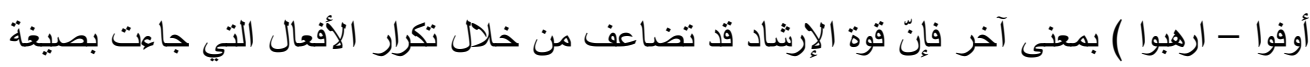

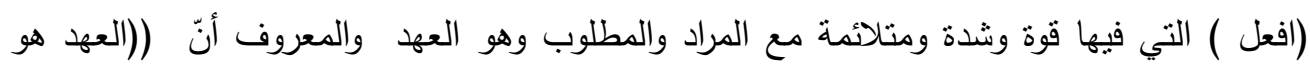

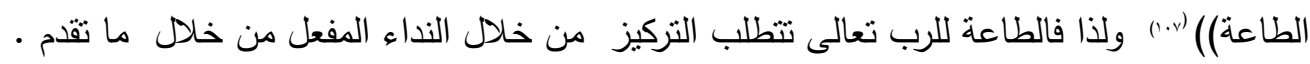

والمعروف أن أساليب الطلب النحوية قد تجتمع مع بعضها وتسهم في خلق حالة منوازية من

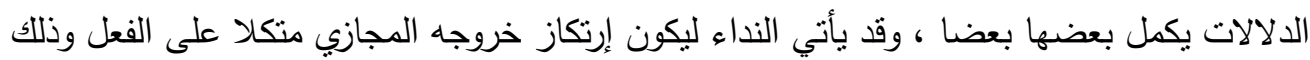

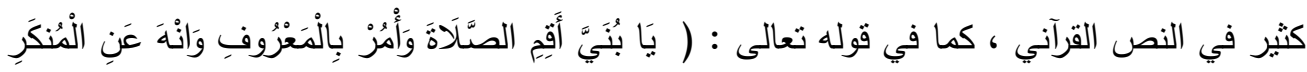

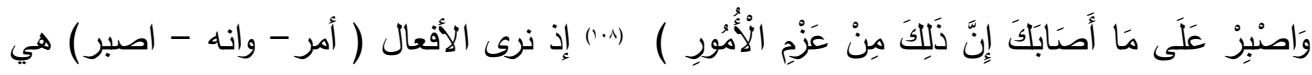

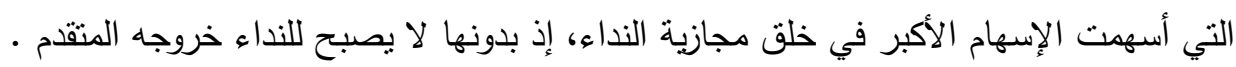

وقد يأتي الفعل متقدما أمام اسلوب النداء فيعمل على تصعيد الخروج المجازي بل قد يضع اللبنة

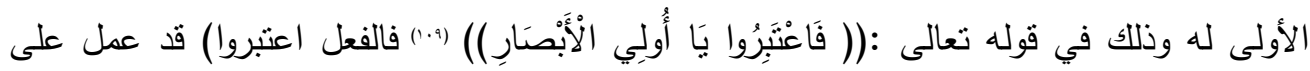

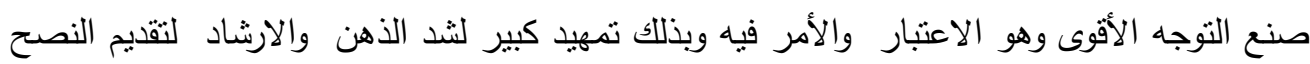
الذي جاء بعد ذللك يا (أولي الابصار ). 
وقد يكون الخروج المجازي محصورا بالجمل الفعلية التي تهيكل أطره كما في قوله تعالى( بَّا

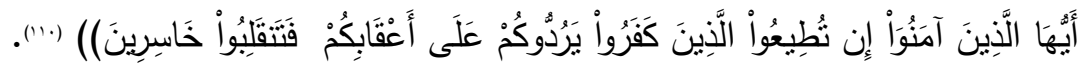

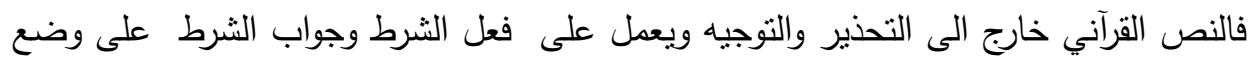
الأطر المحددة لماهية التحذير وأسبابه وعواقبه(ان تطيعوا الذين كفروا يردوكم على أعقابكم ).

وللفعل اثر كبير في ماهية الخروج وزيادة أنزه وقد يتعدد الفعل ليزيد من قوة الطرح المراد تقديمه

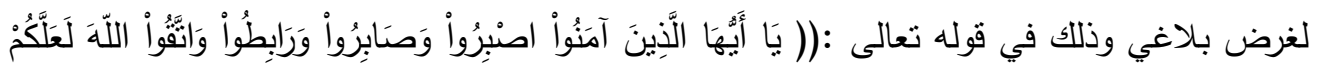

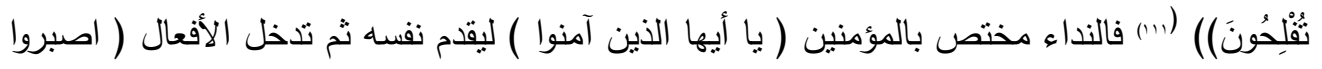

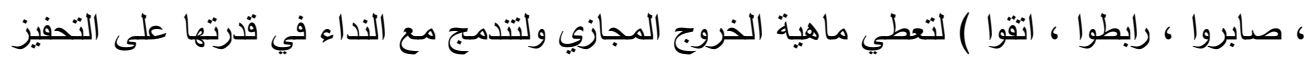

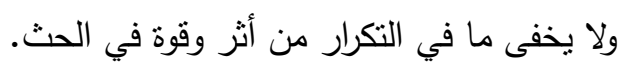

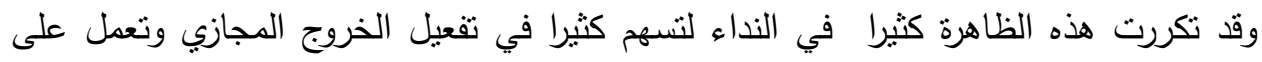

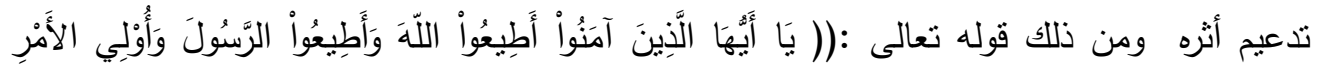

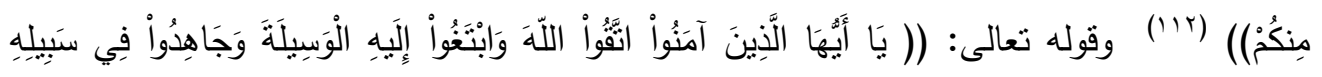

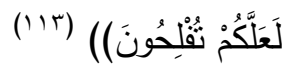

وقد يأني الفعل ماضيا مع النداء القرآني ليسهم في تقرير الدلالة وإثباتها ؛ لأنّ الفعل الماضي

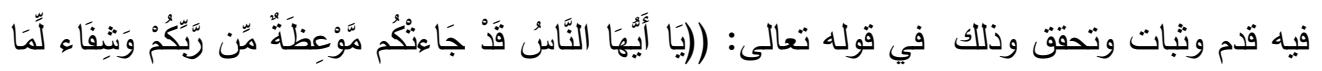

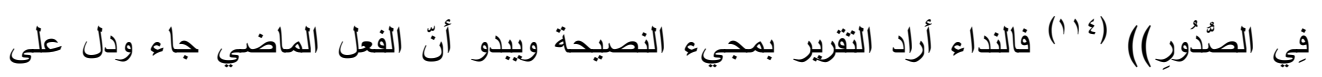

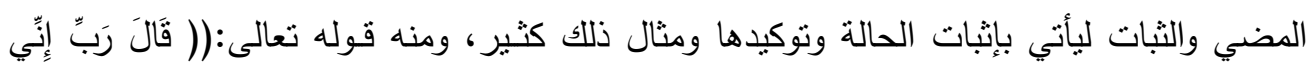

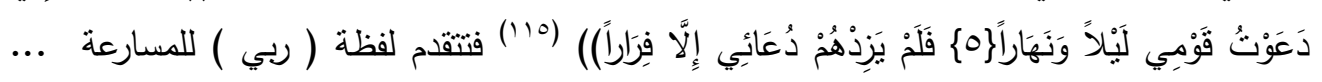

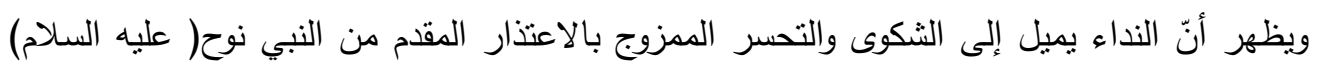

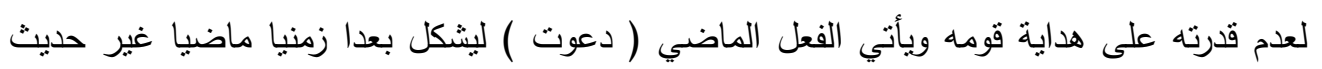

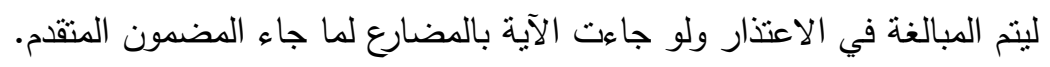

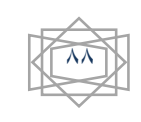


العــــــدد الثاني والعشرون

مجلــــة كليــــة التربيـــة

ومثنال ما تقدم ما ورد في كلام نوح عليه السلام في قوله تعالى :)( قَالَ نُوحُح رَّبِّ إِنَّهُمْ عَصَوْنِي

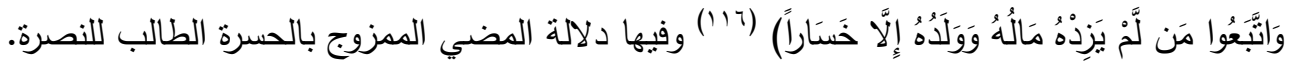

والفعل المضارع جاء في النداء القرآني ليبين الأثز الكبير في الخروج المجازي والفعل المضارع يعطي نوعا من الاستمرارية والتجسيد الذي يهيكل صورة الخروج المجازي ويحدد أطره ومن ذلك قوله

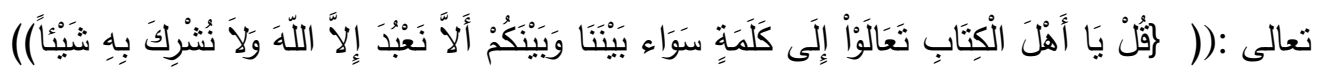

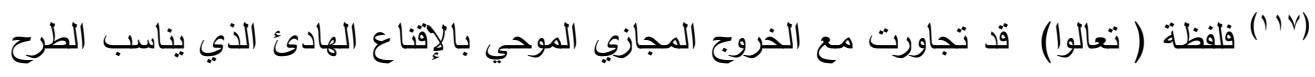

المراد باه بث الدعوة ومدها.

ويعطي الفعل المضارع النداء نوعا كبيرا من التجسيد ويظـهر ذللك في قوله تعالى:(( وَ يَا قَوْمِ

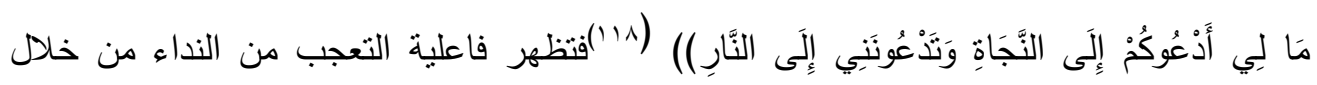
الأفعال( أدعوكم، تدعوني) ولا يخفى ما للفعل المضارع من قدرة على التجسيد مما يزيد النداء

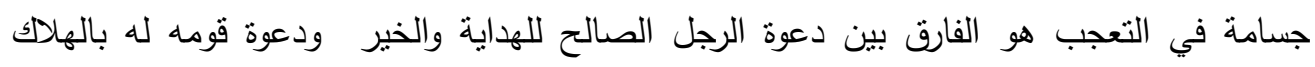

والنار . 


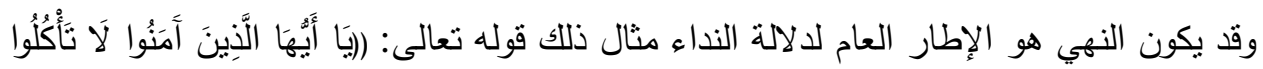

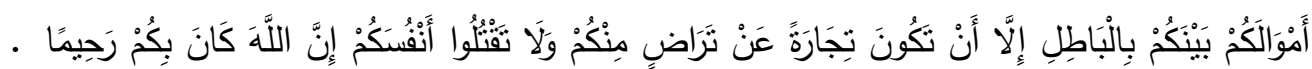

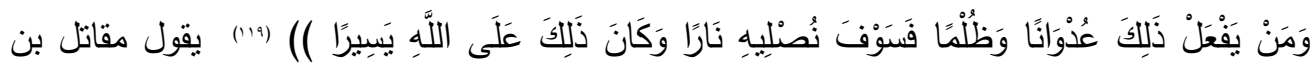

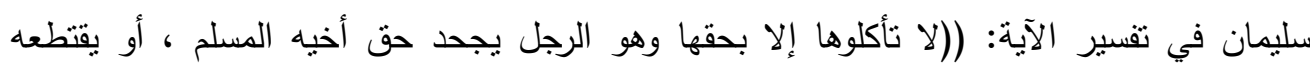

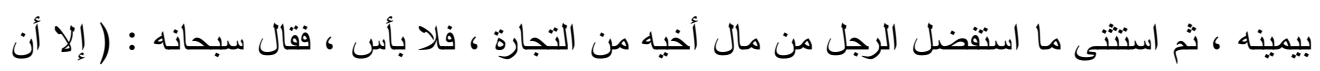

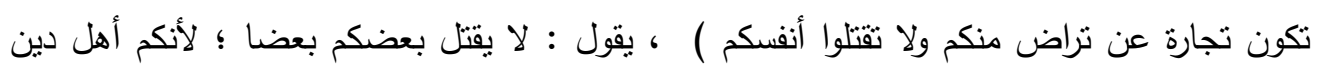

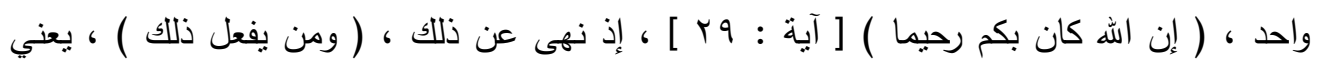

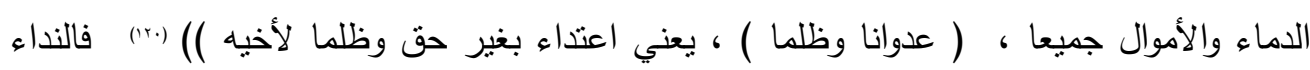

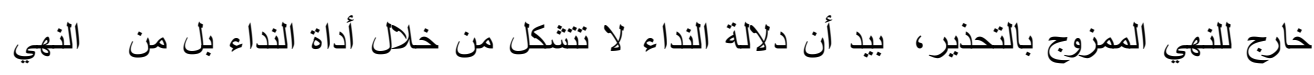

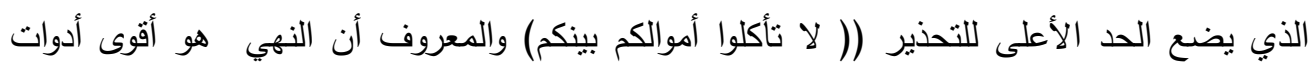
الطلب ، وبهذا يكون التحذير المنتكل في النداء على أعلى مراحله.

)): وقد تتشكل دلالة النداء من خلال النهي الممزوج بالتحذير كما في قوله تعالى

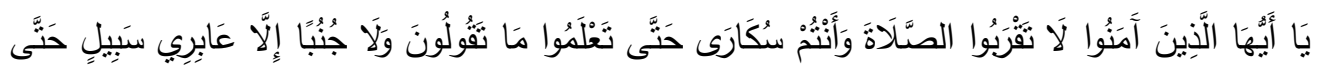

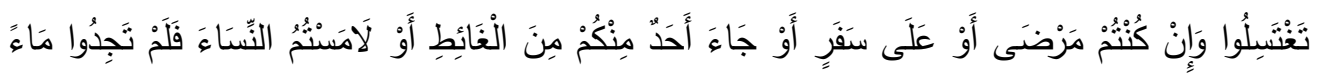

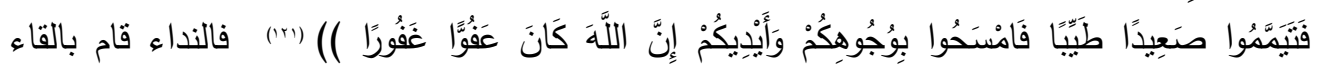
الجانب التتبيهي للطرح الدقدم و أن النهي قد أركز الدلالة المراد ايصالها للمتلقي.

وقد يجتمع الأمر والنهي كسياق متحد يتعاضد من أجل اخراج دلالة النداء ' كما في قوله

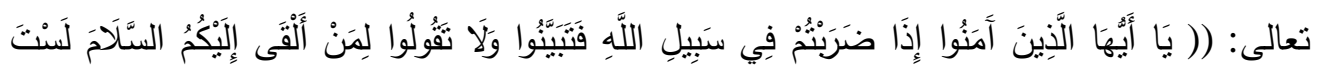

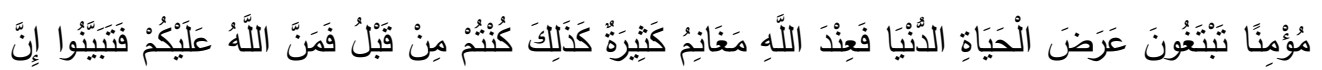

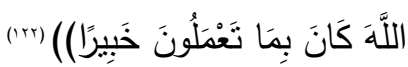

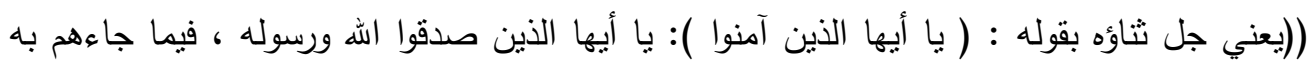

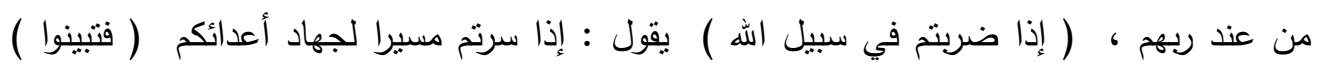


يقول : فتأنوا في قتل من أثنكل عليكم أمره ، فلم تعلموا حقبقة إسلامه ولا كفره ، ولا تعجلوا فتقتلوا من

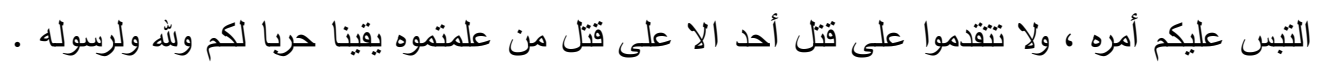

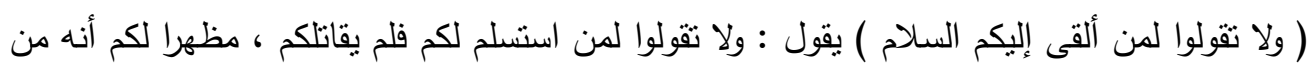

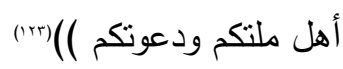

فالنداء المتقدم موجه إلى الذين آمنوا في باب التوجيه والإرشاد بيد أن دلالته لا تتكثف الا من

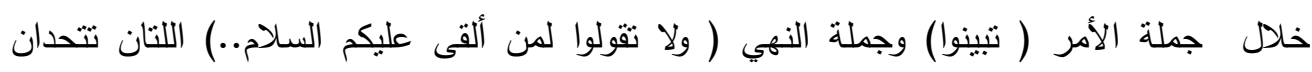

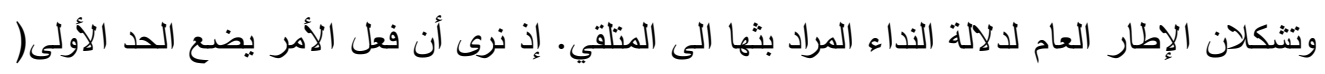

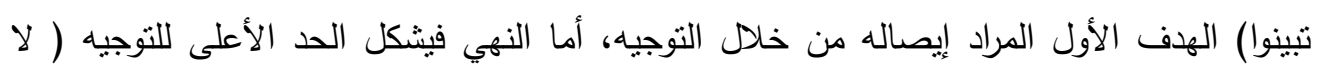
تقولوا) لأنه جاء بصيغة النهي الني هي من أقوي صيخ الطلب.

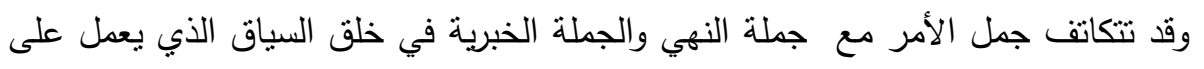

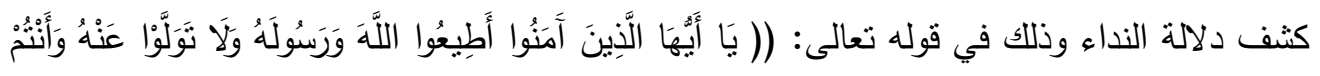

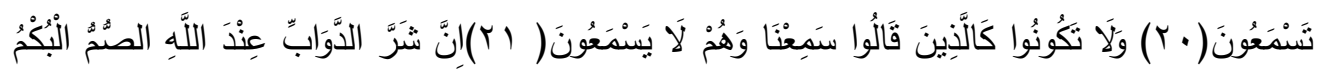

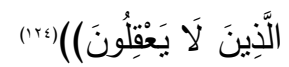

النداء في دلالته خارج الى الارشاد والتوجيه الممزوج بالتحذير ، ويظهر أن الدلالة المجازية لا

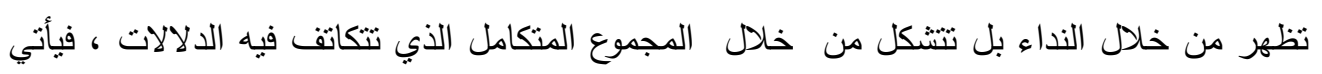

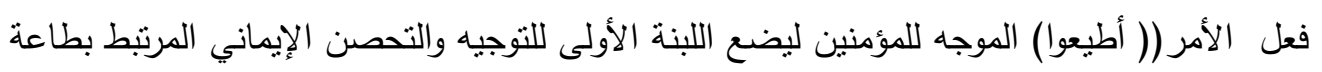

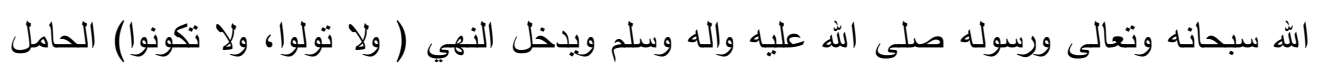

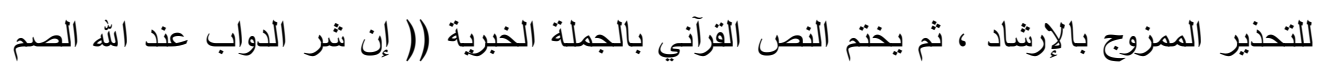

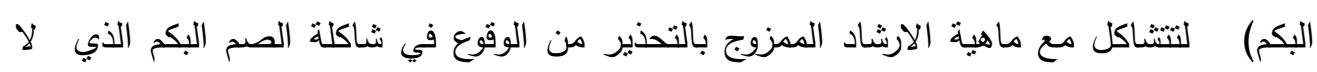

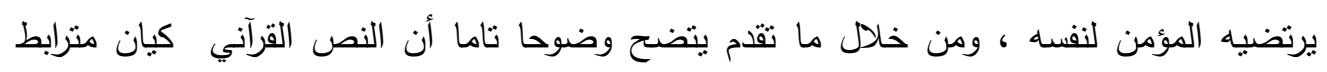

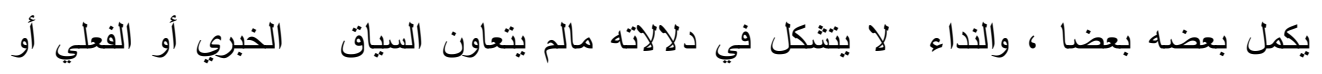

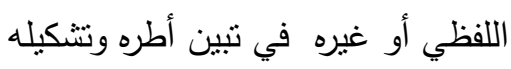




\section{السياق الصوتي واثثره في دلائة النداء}

وللحرف أثر كبير وفاعل في الخروج المجازي للنداء ؛ لأنّ في الحرف ينم الحفاظ على ألى ألهاء

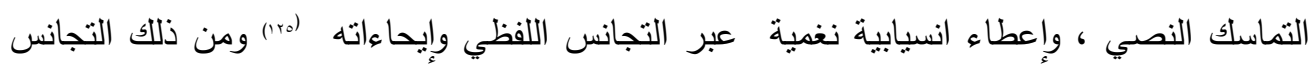
في الحروف القرآنية وصولا لإظهار دلالة الخروج المجازي من خلال سطوة وهيمنة الحرف وجرسه

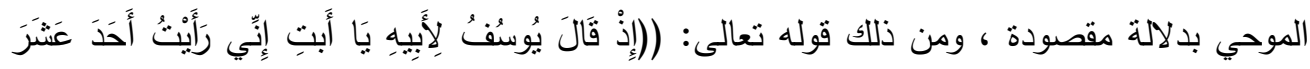

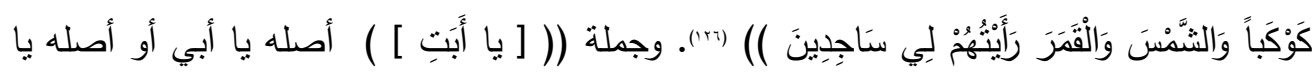

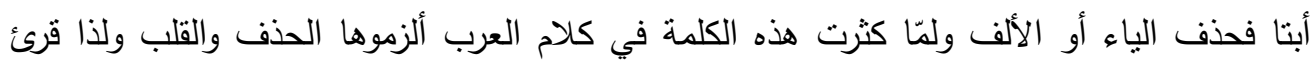

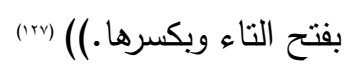

فالملاحظ أنّ طبيعة الرويا وأهميتها قد دعت يوسف (عليه السلام ) أن يجلب كل انتباه والده

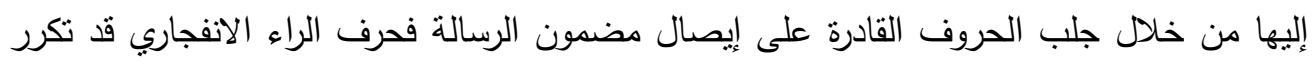

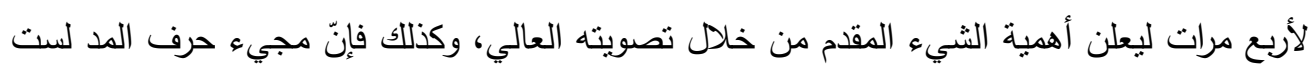

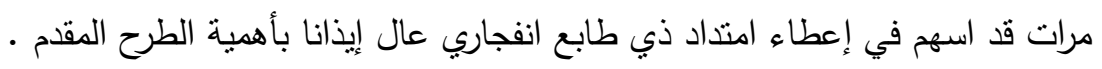

إن النص القرآني في النداء قد ييرز على وفق خط إيقاعي يوصل للالالة عن طريق الحروف

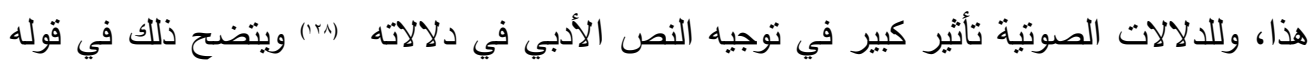

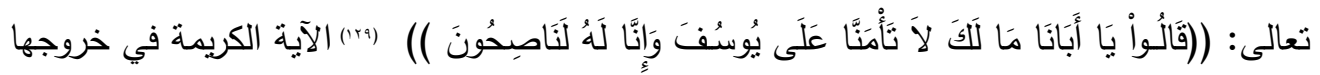
المجازي واقعة في باب النطمين المشوب بالمكر والخداع في إقناع نبي الله يعقوب (عليه السلام)

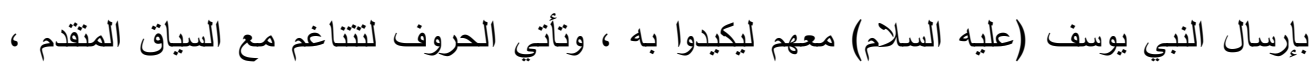

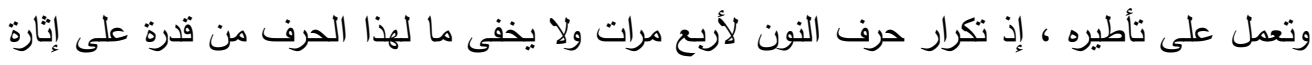

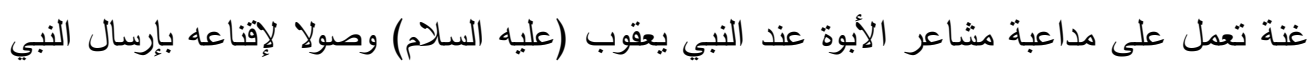

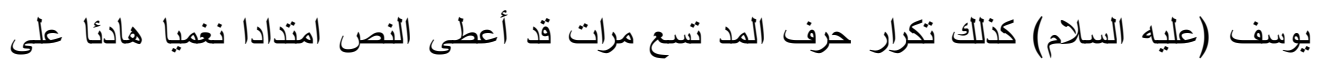

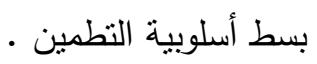


ويظهر للحرف في النداء اثر كبير في الخروج المجازي ، ومن ذلك قوله تعالى : (يس\})

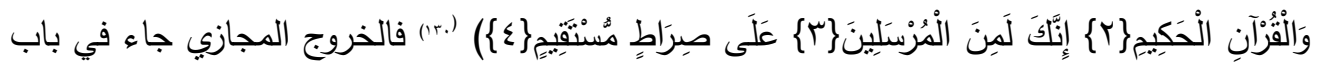

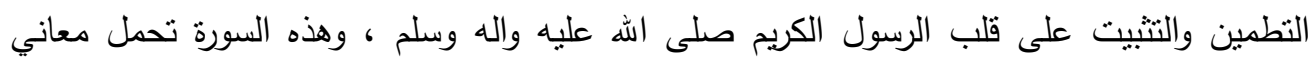
رمزية ألقاها الله سبحانه وتعالى إلى رسوله صلى الله عليه واله وسلم ،وكانت سورة (طه) مبندئة

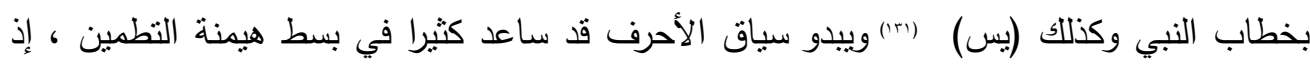

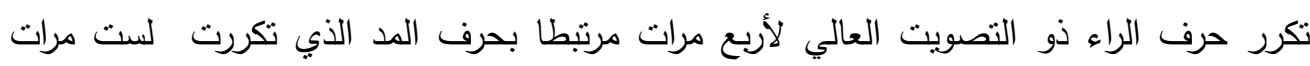

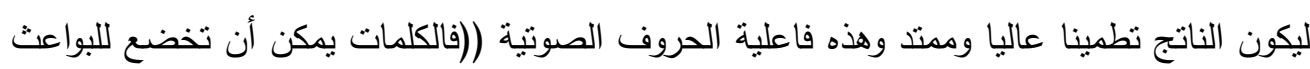
المحركة لها فتصبح شفافة أو معتمة ويتم هذا على مستويات صوتية ودلالية () (بrr)

وقد يكون للحرف والفعل الأثر الأكبر في إظهار الدلالة المجازية المراد بثها الى المتلقي ، ومن

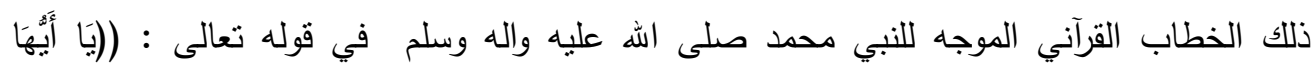

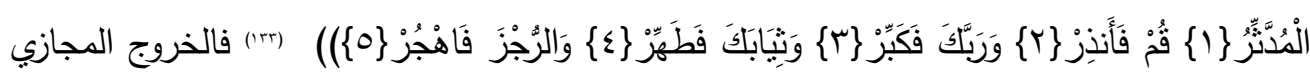

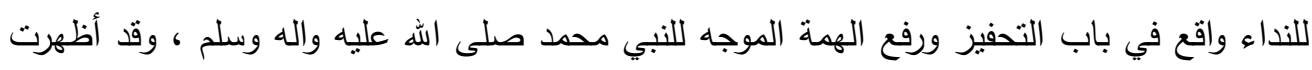
صيغة (افعل ) أثرا كبيرا في تقوية الخطاب وكنلك فان تكرار حرف الراء الانفجاري واستمرارية

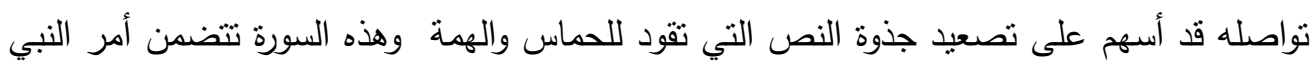

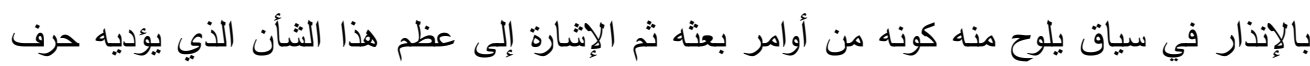
الراء

وقد يكون التتديد في الحروف وسيلة في إيصال الدلالة على اعتبار (( أن النحو وسيلة تكملية

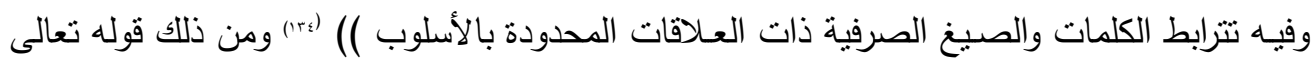

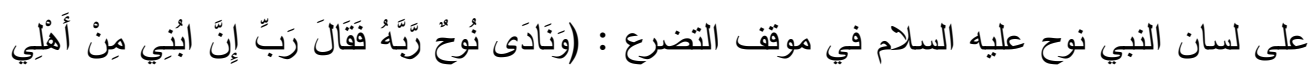

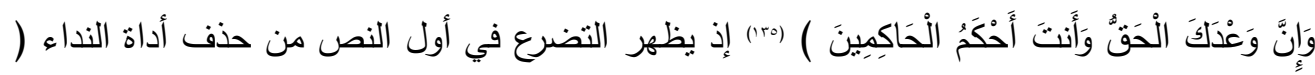

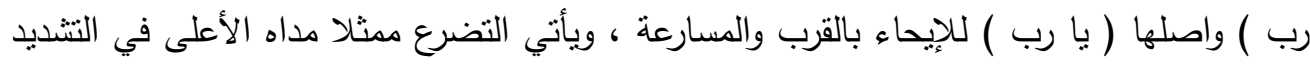

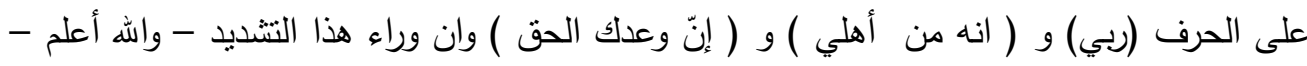

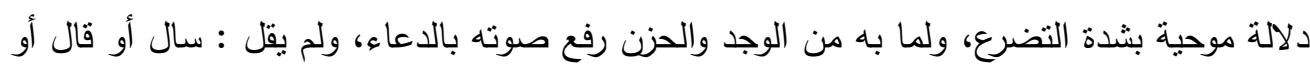

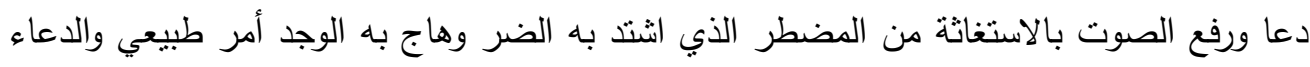

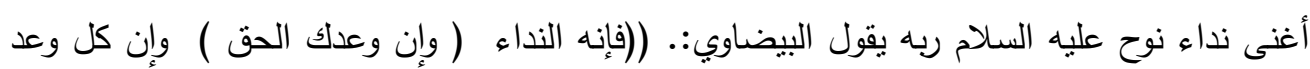

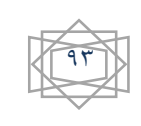


تعده حق لا يتطرق إليه الخلف وقد وعدت أن تتجي أهلي فما حاله أو فما له لم ينج ويجوز أن يكون

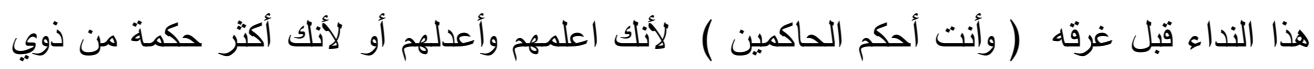

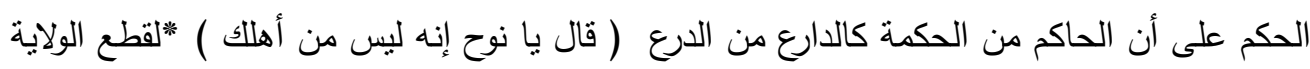

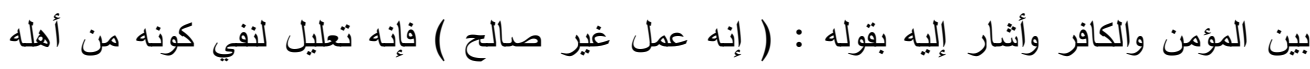

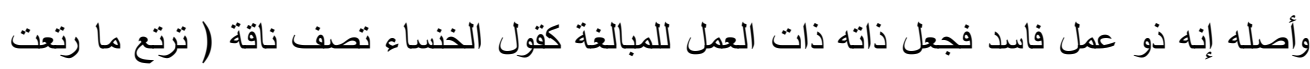

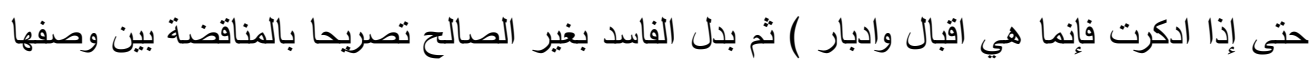

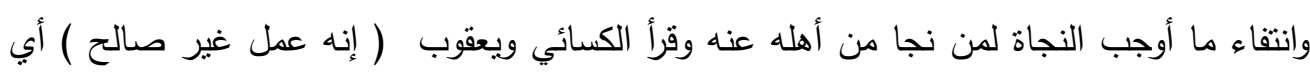

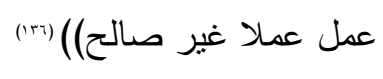

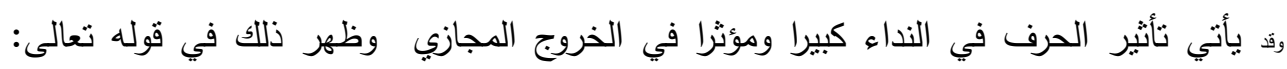

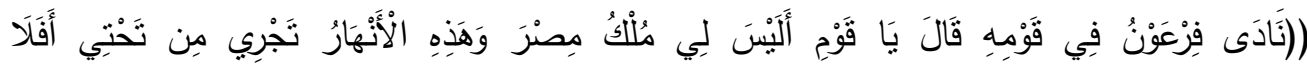

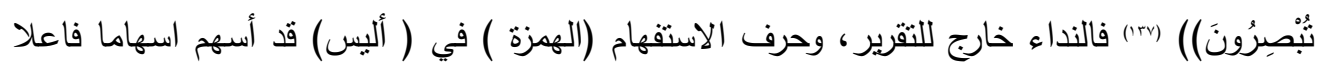
في إثبات حالة التقرير وإركازها، لقصرها وقدرتها على إثارة التساؤل المفضي للتقرير .

وقد يأتي الحرف ليعطي الامتداد النغمي القادر على الاحاطة بالإطار المجازي للنداء و أمتلة ذلك

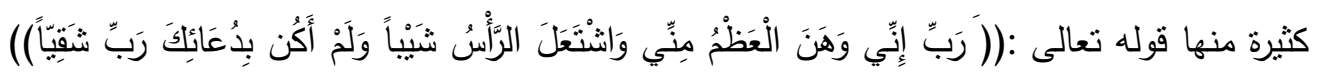

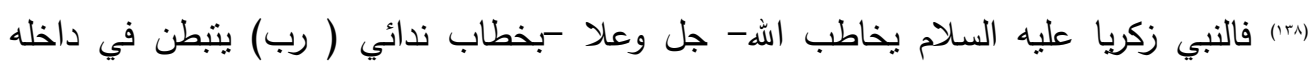

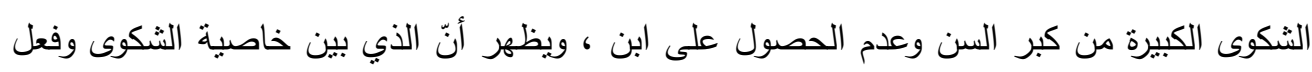

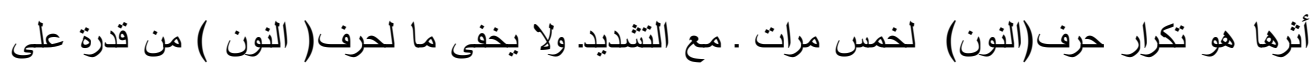

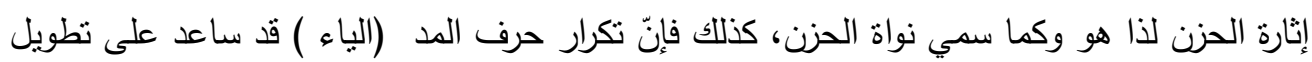
وقفة الحزن لما له من خاصية الامتداد.

وظاهرة تكرار الحرف في النداء كثيرة في القرآن الكريم وهي تكثَف عن ما تتضمنه النفس من

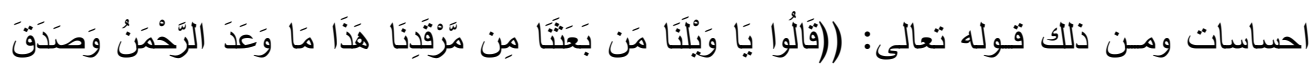

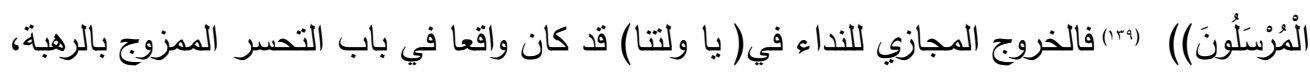

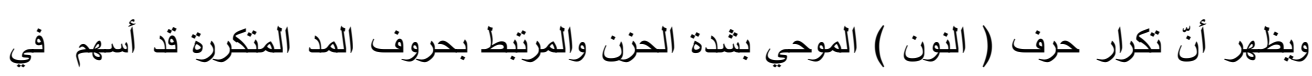
رصد ماهية الخروج المجازي وقولبتها. 


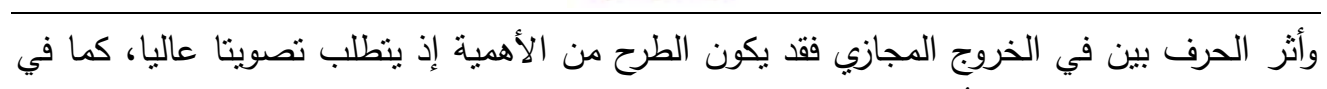

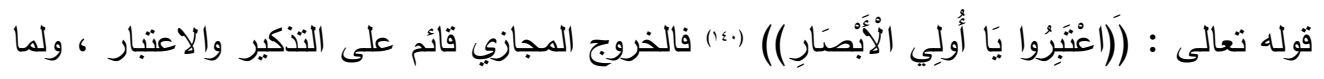

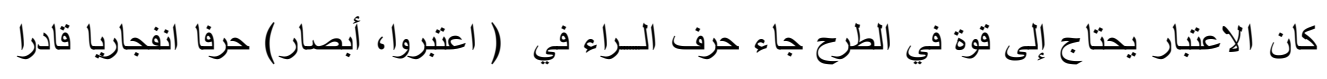
على شد المتلقي الى أهمية الطرح وتتبيهه وحثه .

ويظهر أثزر الحرف في مواقف الثدة والتقريع كبيرا في النداء القرآني، ومنه قوله نعالى : (وَامتَّازُوا

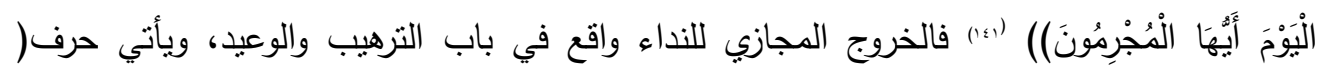

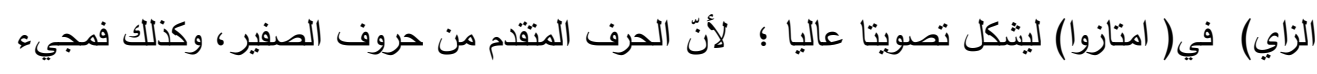

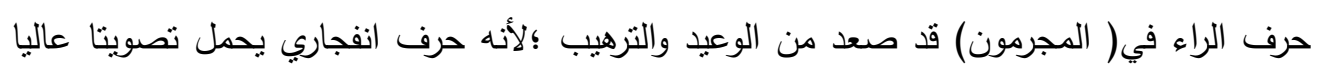

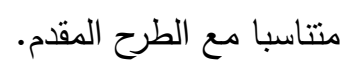

ويبدو الحرف في النداء القرآني متتاغما مع المواقف التي تتطلب انتباها من المخاطب ، كما في رفع

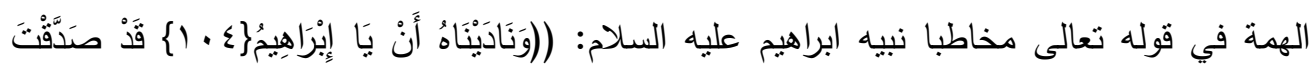

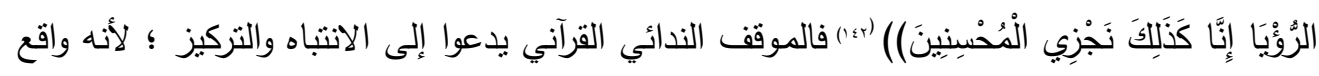

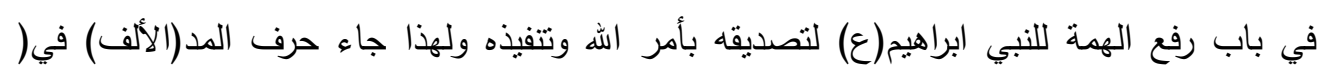

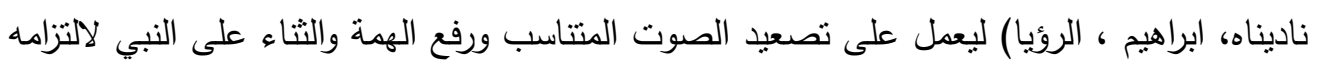

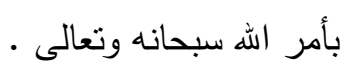


النتائج التي توصل لها البحث

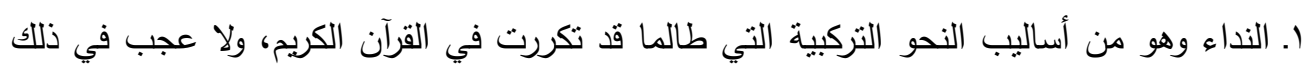

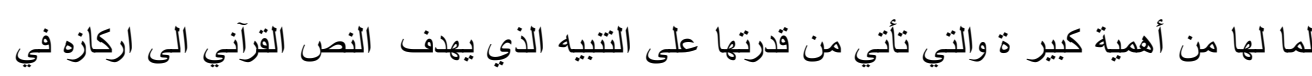
ذهن المتلقي.

ك. أدوات النداء على الرغم من كثرتها الا أنها لم تكثف عن الوجه الحقيقي لدلالة النداء بقدر ما

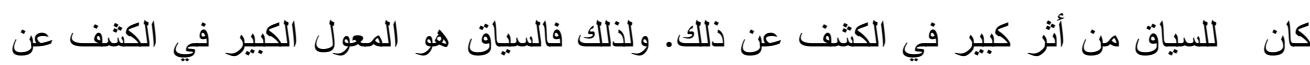

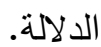

r. للجمل أثز كبير في الدلالة والجمل على أنواع منها الخبرية ، ومنها الفعلية ومنها الاسمية ومنها الثرطية، ولكل من هذه الجمل أدوات خاصة وسياقات تعمل على قولبة الإطار المجازي للنداء وتعمل على صنع دلالاته المراد بثها الى المتلقي.

ع. للأفعال أثز كبير في صنع دلالة النداء من خلال السياق الذي بأتي به وقد يصبح الفعل بمثابة السياق الذي يكنه الدلالة ويعمل على ايقاعها في ذهن المنلقي.

ه. النهي صيغة من صيخ الطلب وهي أقواها لأنها تفيد التأبيد ، وعندما تأني في سياق النداء تضع الجانب المهم الذي يعمل النداء على بسط الفرش والتمهيد له.

I. كذللك للحروف اثز كبير في السياق تعمل على رفع حالة الخروج المجازي وتساعد على ايصاله. V. قد تجتمع الكينات المتقدمة جميعا وتساعد بعضها في ايقاع دلالة النداء.

A. القرآن الكريم هو مادة اعجازية وبيان عال لا يمكن أن يأتي في حرف أو تقديم أو تأخير مالم يكن له سبيية ودلالة مراد ايصالها. 
عنوان البحث( السياق وأثره الدلالي في الخروج المجازي لأسلوب النداء القرآني) والنداء من

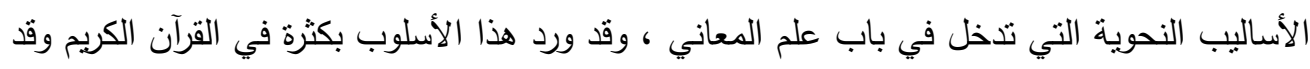

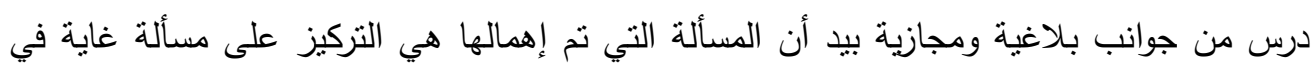

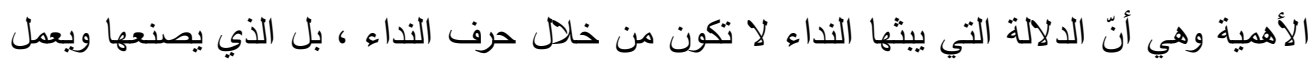

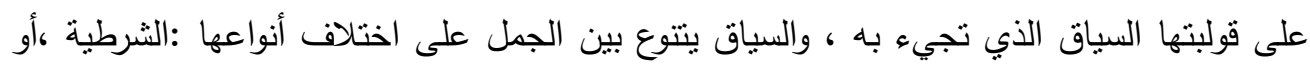

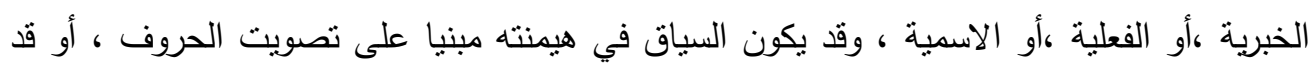

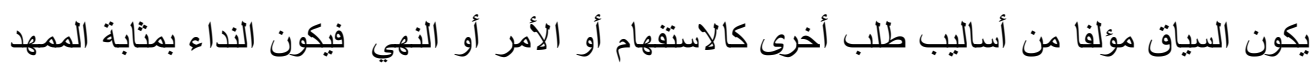

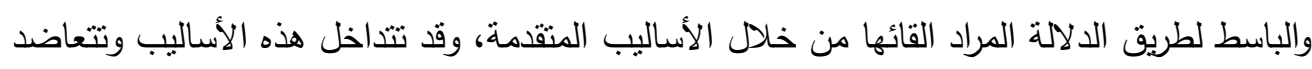
لتشكل سياق نداء قادر على كثف الدلالة المراد بثها إلى المتلقي. 


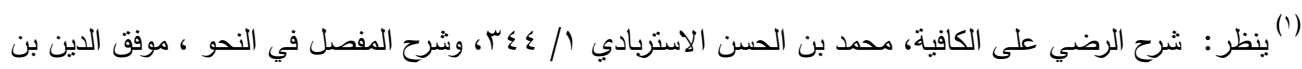

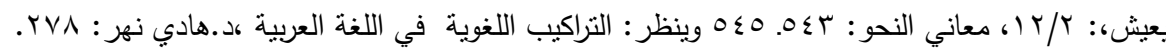

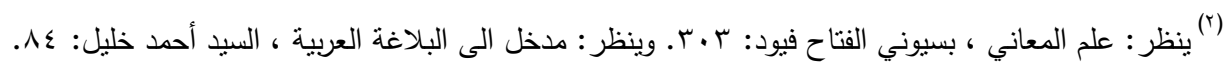

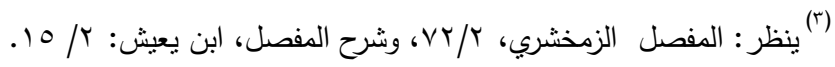

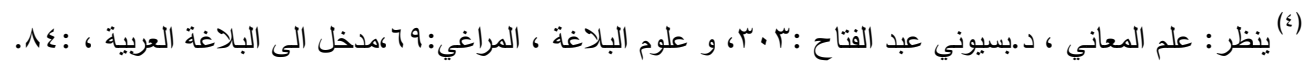

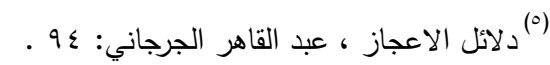

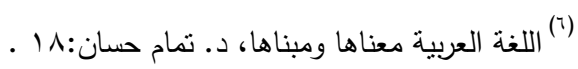

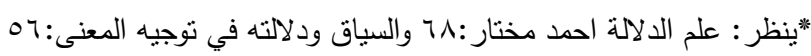
(l)

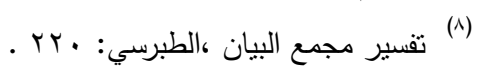

$$
\text { (9) }
$$

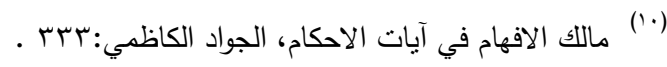

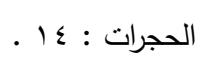

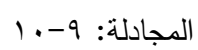

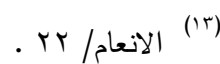

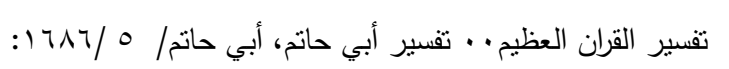

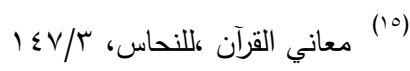

$$
\begin{aligned}
& \text { (T) }
\end{aligned}
$$

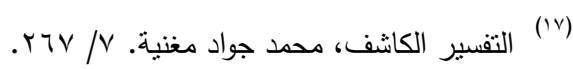

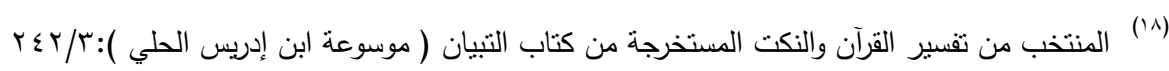

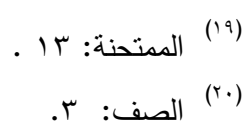

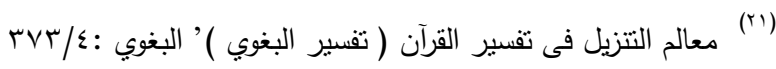

$$
\begin{aligned}
& \text { الانعام: (rr) } \\
& \text { (4) الانعام: (r) }
\end{aligned}
$$

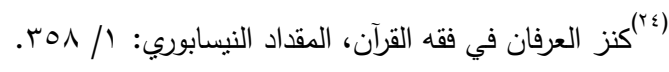




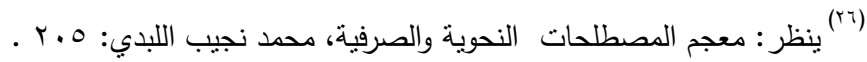

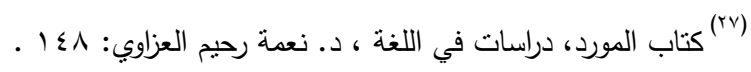

$$
\text { ـابراهيم /(r) }
$$

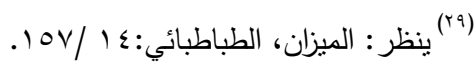

(r·)

$$
\text { . •.|l(r) }
$$

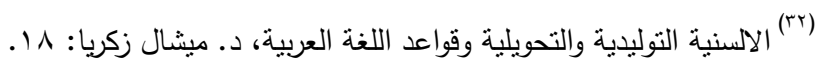

$$
\begin{gathered}
.1 r 0: b^{(r r)} \\
. \vee 9 ط^{(r \varepsilon)}
\end{gathered}
$$

(ro)

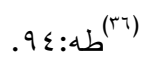

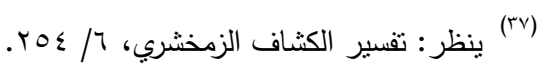

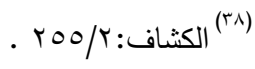

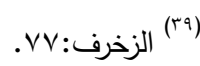

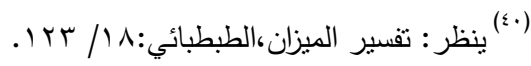

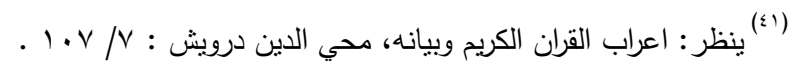

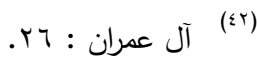

$$
\begin{aligned}
& \text {. } 91 \text { آل عمران }
\end{aligned}
$$

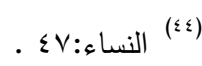$$
\text { . } 10 \text { : المائدة: (10) }
$$

$$
\text { (\&v) }
$$

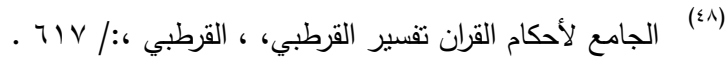

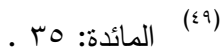

$$
\begin{aligned}
& \text { 9. (0.) (0.) (لمائدة) }
\end{aligned}
$$

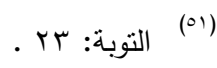




\section{مجلــــة كليــــة التربيـــة}

$$
\begin{aligned}
& 9 \text { (or) } \\
& \text { (0r) } \\
& \text {. الاعراف : } \\
& \text { (0) }
\end{aligned}
$$

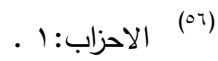

$$
\begin{aligned}
& \text { طه: (ov) } \\
& \text { (ㅅ) } \\
& \text { (09) }
\end{aligned}
$$

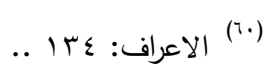

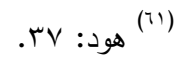

$$
\begin{aligned}
& \text { (ז') المائدة: } 117
\end{aligned}
$$

جواهر الحسان في تفسير القرآن ( تفسير الثعالبي )تحقيق : الدكتور عبد الفتاح أبو سنة - الثيخ علي محمد معوض

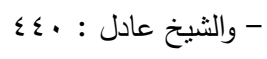$$
\text { . يوسف: (1乞) }
$$$$
0: 0 \text { : (70) }
$$$$
\text { (1) }
$$$$
\text { T) : (TV) }
$$$$
\text { الحاقة : (ri) }
$$$$
\text { . TV : المائدة : (79) }
$$$$
\text { . } 1 \text { / المائدة: }{ }^{(v \cdot)}
$$

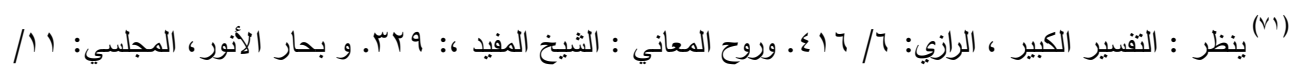

$$
\begin{aligned}
& r-1: \text { bه }^{(\mathrm{rr})}
\end{aligned}
$$

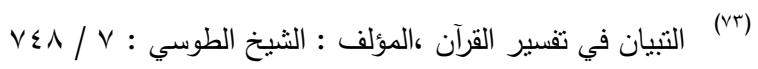

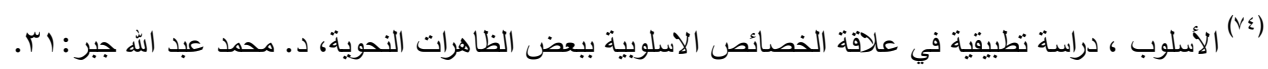

$$
\text { التحريم: (vo) }
$$

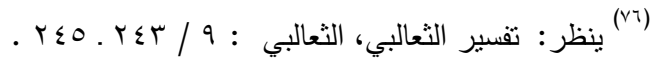




$$
\begin{aligned}
& \text { تفسير البيضاوي، البيضاوي:rV) } \\
& \text { الزخرف : (ㅅ) } \\
& \text { ينظر : (va) }
\end{aligned}
$$

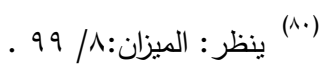

$$
\begin{aligned}
& \text { (ㅅ) }
\end{aligned}
$$

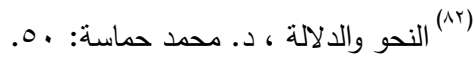

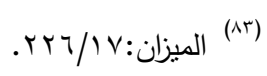

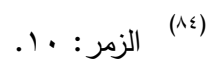

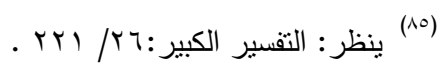

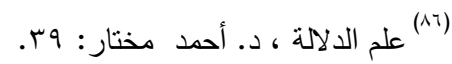

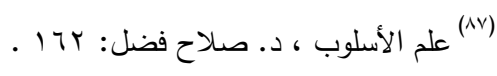

$$
\begin{aligned}
& \text { (^^) }
\end{aligned}
$$

$$
\begin{aligned}
& \text { ينظر : الميزان: (Aq) }
\end{aligned}
$$

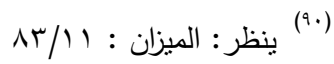

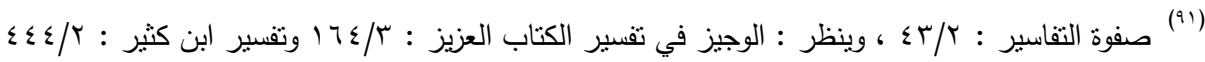

$$
\begin{aligned}
& \text { والميزان: 109/1 } \\
& \text { (9r) }
\end{aligned}
$$

(9)

$$
\text { . . . (9६) }
$$

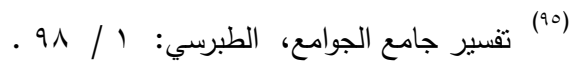

$$
\text { . }
$$

ينظر : صفوة التفاسير :Ty)

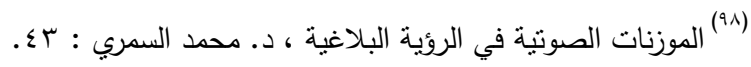

$$
\text { (199) }
$$

(...(1) الخوف الفاظه وسياقاته في القران الكريم ، د. أحمد جواد العتابي:ج.

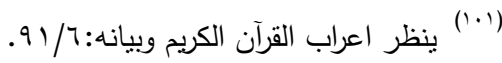

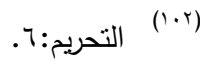




$$
\begin{aligned}
& \text { (-r) }
\end{aligned}
$$

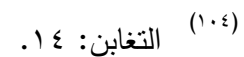

$$
\begin{aligned}
& \text { ينظر : الميزان: (1.0) } \\
& \text { V) : النساء }
\end{aligned}
$$

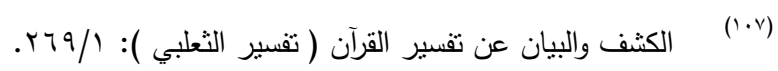

$$
\begin{aligned}
& \text {.IV: لقمان } \\
& r: \text { r.9) } \\
& \text { آل (1).) } \\
& \text { r.. : : ('l') } \\
& \text { (الن } \\
& \text { ( المائدة: (1/r) } \\
& \text {. ov : يونس (1) (1) } \\
& \text {. 1-0: : نوح : } \\
& \text {. r : نوح: } \\
& \text { (آل عمران: (1'r) } \\
& \text {. غافر: (1)14) } \\
& \text { (1/9) }
\end{aligned}
$$

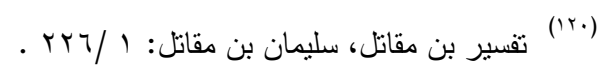

$$
\begin{aligned}
& \text { (1r) } \\
& 9 \text {. } 9 \text { ـ (Irr) }
\end{aligned}
$$

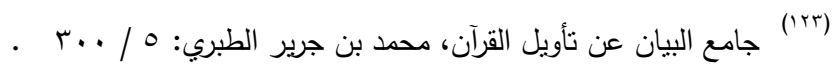

$$
\begin{aligned}
& \text { (ro) }
\end{aligned}
$$

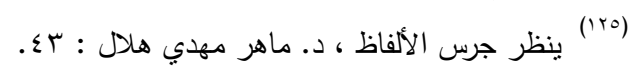

$$
\begin{aligned}
& \text { يوسف: ع (Tr) } \\
& \text { (ITY) }
\end{aligned}
$$

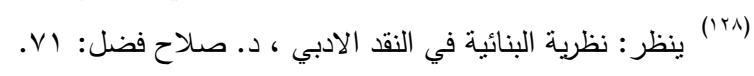

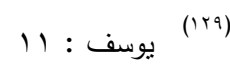




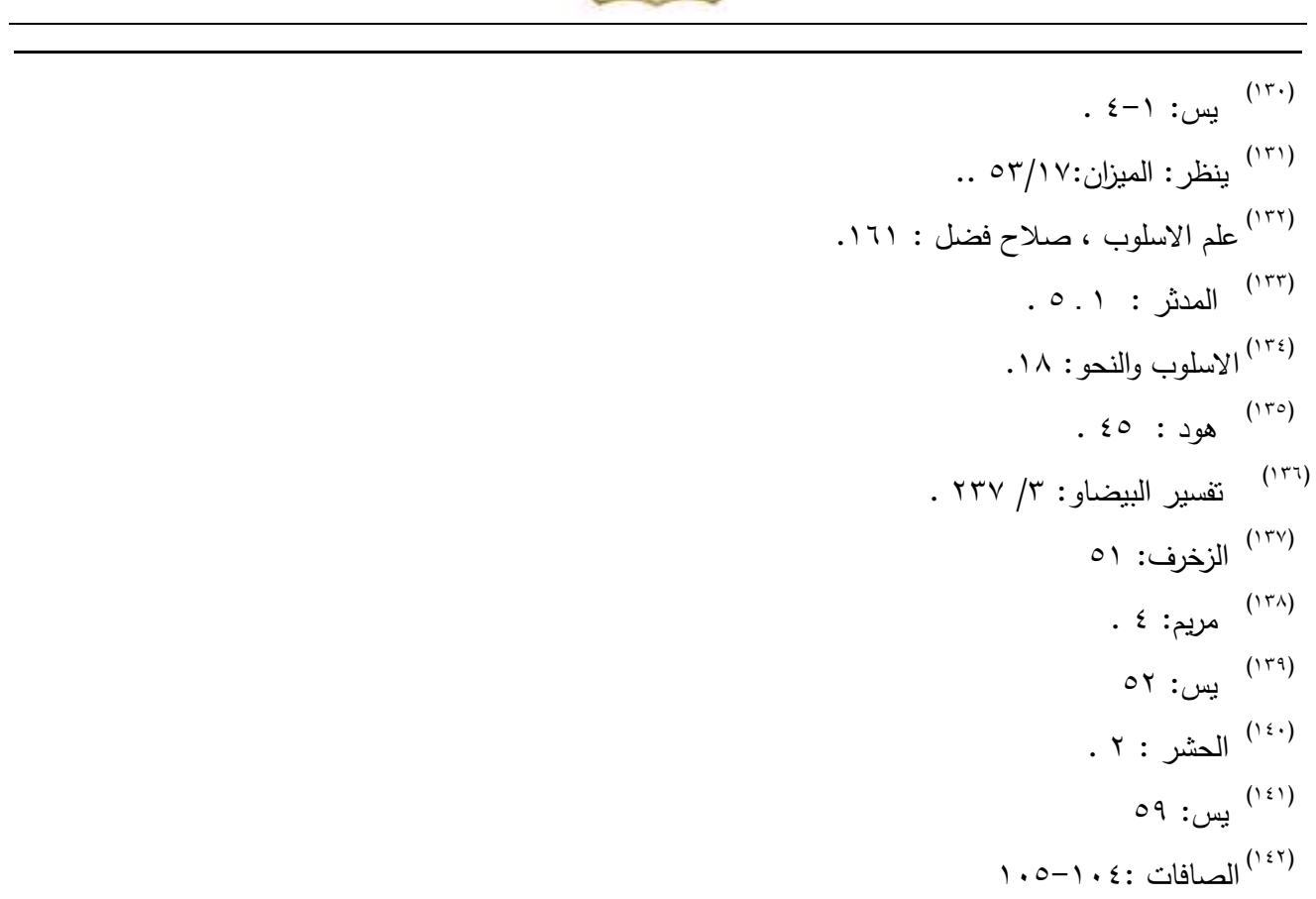


المصادر والمرجع

ـ القرآن الكريم

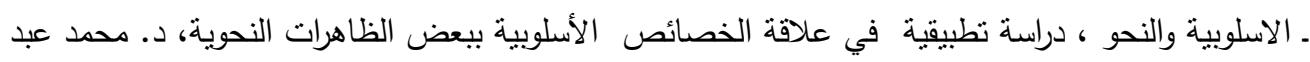

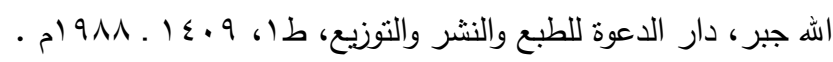

. إعراب القران الكريم وبيانه تأليف الأستاذ محيي الدين درويش /مطبعة سليمان زاده/ طץ ، I I هـ.

ـ الألسنية التوليدية والتحويلية وقواعد اللغة العربية، د. ميشال زكريا، المؤسسة الجامعية للاراسات والنشر

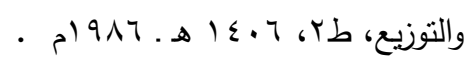

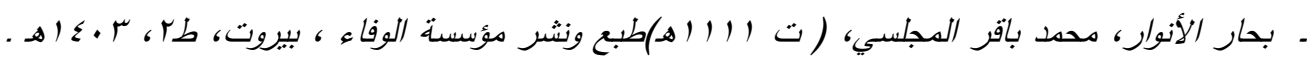
. 1914

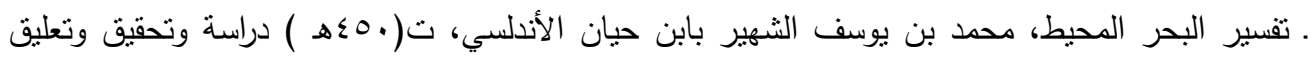

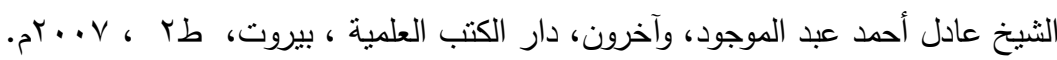

• بلاغة الكلمة في التعبير القرآني، د. فاضل صالح السامرائي، دار عمار للنشر والتوزيع، طه، م. . بام .

ـ البلاغة فنونها وأفنانها، علم المعاني ، د. فضل حسن عباس، مكتبة الحسن للنشر والتزيع، ط؟، عمان919 ام.

ـ التراكيب اللغوية في العربية دراسة تطبيقية ، د. هادي نهر، ساعدت الجامعة المستتصرية على نشره، مطبعة

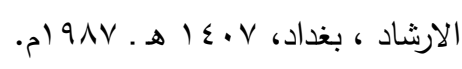

ـ تفسير الثعالبي المسمى بالجواهر الحسان في تفسير القرآن ، عبد الرحمن بن محمد مخلوف أبي زيد

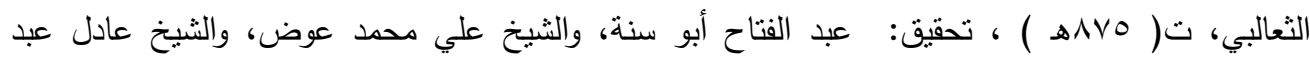

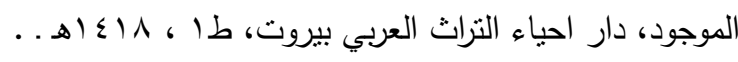


ـ تفسير جوامع الجامع المؤلف، : الثيخ الطبرسي ،ت( : : مؤسسة النشر الإنسلامي التابعة لجماعة المدرسين بقم المشرفة

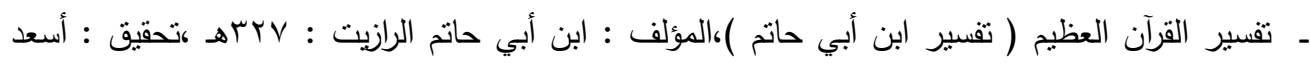

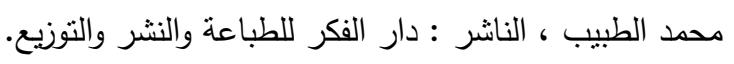

. التفسير الكاشف ،المؤلف : محمد جواد مغنية ،الوفاة : . ..؟ (، هـ ،سنة الطبع : آذار ( مارس ) 1911،1الناشر : دار العلم للملايين - بيروت - لبنان، : دار العلم للملايين - بيروت - لبنان.

ـ التفسير الكبير أو مفاتيح الغيب فخر الدين الرازي، محمد بن عمر بن علي الرازي، دار الكتب العلمية ،

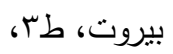

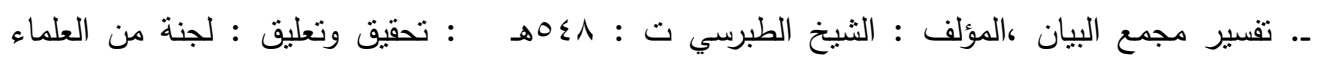

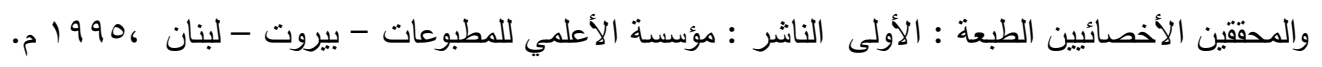
ـ تفسير مقاتل بن سليمان ،المؤلف : مقاتل بن سليمان (ت.0. اهـ ) تحقيق: أحمد فريد، الطبعة : الأولى

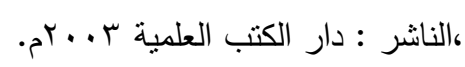

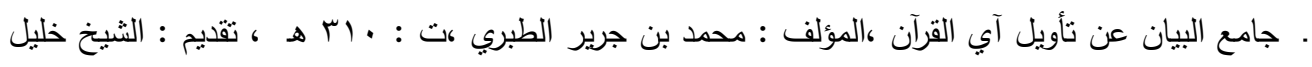

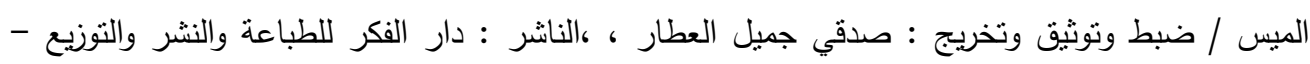

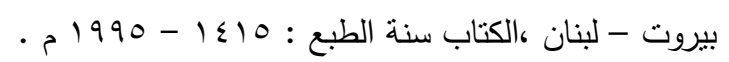

· جرس الالفاظ ودلالتها في البحث البلاغي والنقدي عند العرب ، د. ماهر مهدي هلال ، دار الرشيد للنشر ،

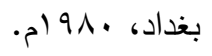

ـ الخوف الفاظه وسياقاته في القرآن الكريم ، دراسة لغوية، د. أحمد جواد العتابي، منشورات ديوان الوقف

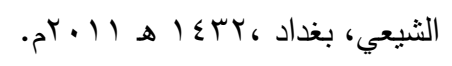

ـ دلاثل الاعجاز ، عبد القاهر الجرجاني، تقديم علي أبو زيقه، للنشر، الجزائر، الم م. 
• روح المعاني في تفسير القرآن العظيم والسبع المثاني أبو الفضل ، شهاب الدين السيد محمود الالوسي،

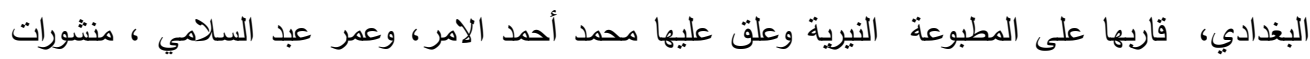
احياء التراث العربي، تارباء

ـالسباق ودلالته في توجيه المعنى/فوزي ابراهيم عبد الرزاق /رسالة دكتوراه- كلية الاداب جامعة بغدادم) 994

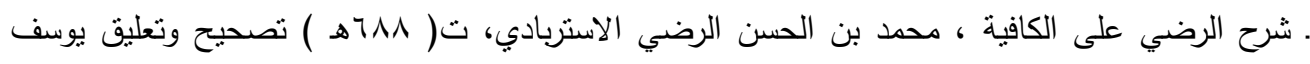

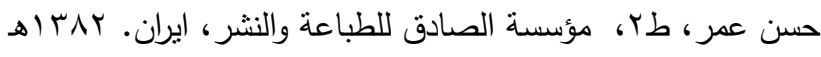
ـ شرح الدفصل في النحو، موفق الدين بن يعيش، منشورات عالم الكتب، بيروت، د. ت. صفوت التفاسير / نأليف محمد علي صابوني / دار القران الكريم بيروت / ط؛ ا191ام. ـ علم الاسلوب ، مبادئه واجراءاته، د. صلاح فضل، دار الثروق، القاهرة ، طا، 19 1ـ هـ ـ 1991 م. . علم الدلالة ، أحمد مختار عمر، منشورات عالم الكتب القاهرة ، طه، 991 م.

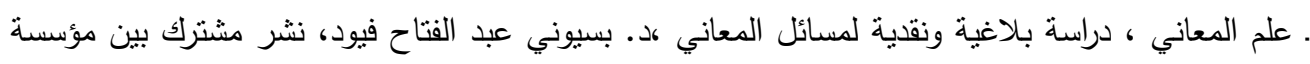

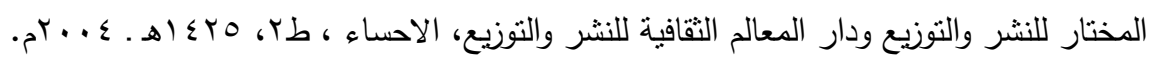

ـ علوم البلاغة ، البيان والمعاني والبديع ، د. أحمد مصطفى المراغي، منشورات ، دار الآفاق، العربية، طا،

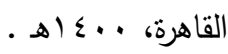

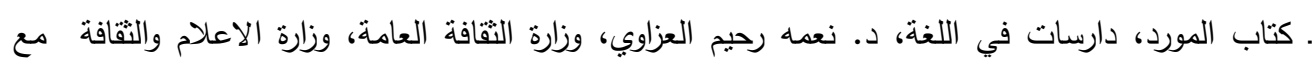

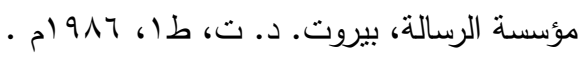

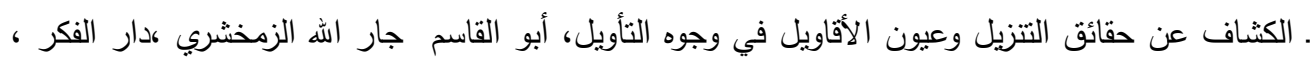

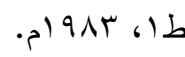


- كنز العرفان في فقه القرآن ،المؤلف : المقداد النسابوري ،الوفاة : بrیهـ ،تحقيق : علق عليه المحقق البارع

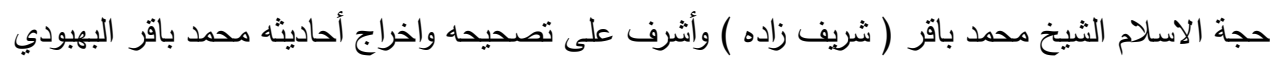

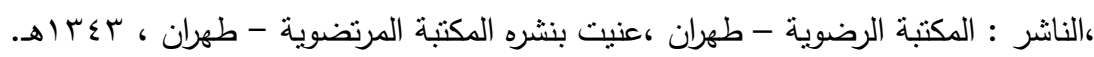
ـ اللغة العربية معناها ومبناها ، د. تمام حسان، ، منشورات البعثة المصرية للكتاب، .p) $9 \vee 9$ ، rb،

ـ اللغة والمعنى والسياق، ترجمة عباس صادق الوهاب ، طا ، دار الشؤون الثقافية العامة ، بغداد ،د.ت .

ـ المدخل إلى دراسة البلاغة العربية ، السيد أحمد خليل ،دار النهضة ، للطباعة والنشر، بيروت، 971 ام . ـ مسالك الأفهام إلى آيات الأحكام ،المؤلف : الجواد الكاظم ، علق عليه وأخرج أحاديثه : الثيخ محمد باقر

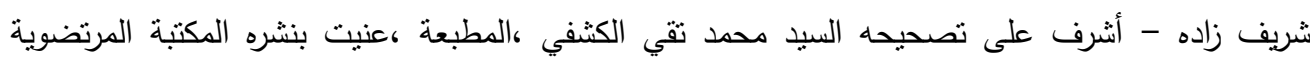

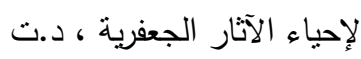

ـ معالم التنزيل فى تفسير القرآن ( تفسير البغوي ) ،المؤلف : البغوي : ت : . 10 هـ ،تحقيق : خالد عبد الرحمن العك ، ،الناشر : دار المعرفة بيروت.

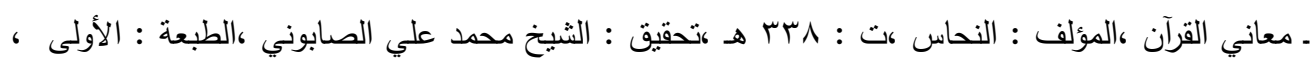

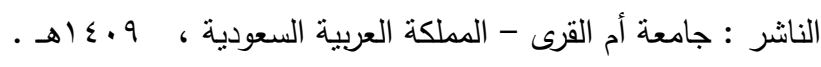
ـ معاني النحو د. فاضل صالح السامرائي، بيت الحكمة للنشر ، والتوزيع والترجمة، ساعدت جامعة بغداد على التى نشره . د.ت

ـ معجم المصطلحات النحوية والصرفية ، محمد سمير نجيب اللبدي ، طبعة دار الثقافة الجزائر ، د. ت.

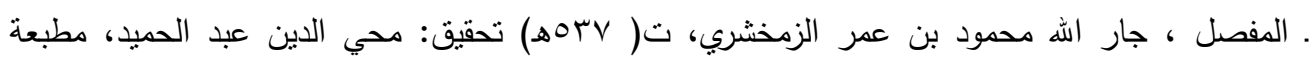

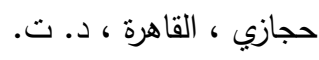

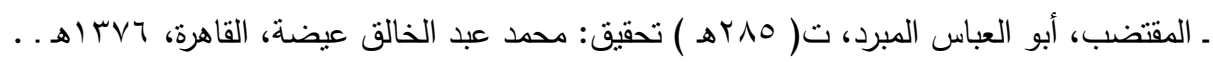


ـ المنتخب من تفسير القرآن والنكت المستخرجة من كتاب التبيان ،المؤلف : ابن إدريس الحلي ،(ت : )، : تحقيق: السيد مهدي الرجائي ، إثراف: السيد محمود المرعشي ،: مطبعة سبد الثهداء عليه السلام 6. ه $1 \leq .9$

ـ الموزنات الصونية في الرؤية البلاغية ، د. محمد السمري، منشورات دار سال، طا، الدار البيضاء ، . 1991

، الميزان في تفسير القرآن للعلامة السيد محمد حسين الطبطبائي، منشورات مؤسسة الاعلمي للمطبوعات ،

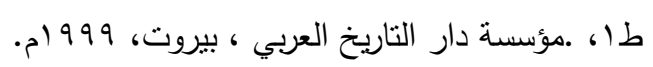

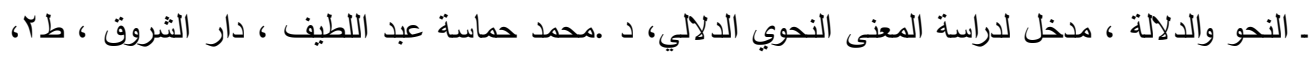
. . . . . . نظرية البنائية في النقد الأدبي، د. صلاح فضل، منشورات دار الثؤون الثقافية العامة، بغداد، 911 ام. 